Studia Anglica Posnaniensia 52(1), 2017

doi: 10.1515/stap-2017-0005

\title{
OBJECTS, WORDS, AND RELIGION: POPULAR BELIEF AND PROTESTANTISM IN EARLY MODERN ENGLAND
}

\author{
JOANNA LUDWIKOWSKA* \\ Centre for Reformation and Renaissance Studies, University of Toronto \\ Faculty of English, Adam Mickiewicz University, Poznań
}

\begin{abstract}
This article deals with selected aspects of popular belief in post-Reformation England as compared to the pre-Reformation popular tradition of the fourteenth and fifteenth century. Through a discussion of the politics of superstition and religiously-shaped concepts of reason in Early Modern England, this article discusses medicinal magic, and the power of objects and words in the context of religion and popular belief, focusing in particular on leprosy and exorcism. By examining the Protestant understanding of the supernatural as well as its polemical importance, the article investigates the perseverance of popular belief after the Reformation and outlines some of the reasons and politics behind this perseverance, while also examining the role of the supernatural in the culture of belief in Early Modern England by tracing the presence and importance of particular beliefs in popular imagination and in the way religion and confessional rhetoric made use of popular beliefs. ${ }^{1}$
\end{abstract}

Keywords: Early Modern England; Protestant; magic; exorcism: leprosy; medicine; preReformation; belief; religion

* $\quad$ Centre for Reformation and Renaissance Studies (CRRS), E. J. Pratt Library, Room 301, 71 Queen's Park Crescent East, Toronto ON M5S 1K7, Canada; Faculty of English, Adam Mickiewicz University, al. Niepodległości 4, 61-874 Poznań, email: joanna.ludwikowska@utoronto.ca.

1 This research is supported by the generous funding of the Polish National Science Centre, project no. 2013/09/N/HS2/02213. I am also very grateful to the Centre for Reformation and Renaissance Studies at the University of Toronto for enabling me to conduct research on the topic of pre- and post-Reformation religiosity with the use of the CRRS's rare book collection, and for granting me access to the Thomas Fisher Rare Book Library and Robarts Library. 


\title{
1. Introduction
}

Increase Mather, a Puritan minister from a long line of Protestant clergymen, in his Remarkable Providences: An Essay For the Recording of Illustrious Providences (1684) narrated an interesting story: in Boston, the home town of God's chosen people and the cradle of the New Jerusalem, a house was possessed by a demon. According to Mather, the house of a Mr. Mompesson

\begin{abstract}
was much disturbed with Knockings, and with Drummings; for an hour together a Daemon would beat Round-heads and Cuckolds, the Tattoo and several other points of War as well as any Drummer. On November 5 [1661], The Daemon made a great noise in the House, and caused some Boards therein to move to and fro in the day time when there was an whole room full of People present. At his departure, he left behind him a Sulphurous smell, which was very offensive. The next night, Chairs walked up and down the Room; the Childrens Shoes were hurled over their heads. The Minister of the Town being there, a Bed-staff was thrown at him, and hit him on the Leg, but without the least hurt. In the latter end of December, 1662, .... [o]ne in the room (by what Authority I cannot tell) said, "Satan, if the Drummer set thee a work give three knocks and no more", which was done accordingly. Once when it was very sharp severe Weather, the room was suddenly filled with a Noisome smell, and was very hot though without fire. This Daemon would play some nasty and many ludicrous foolish tricks. It would empty Chamber-pots into the Beds; and fill Porringers with Ashes. Sometimes it would not suffer any light to be in the room, but would carry them away up the Chimney. Mr. Mompesson coming one morning into his Stable, found his Horse on the ground, having one of his hinder legs in his mouth, and so fastened there, that it was difficult for several men with a Leaver to get it out. .... The Drummer was under vehement suspicion for a Conjurer. He was condemned to Transportation. All the time of his restraint and absence, the House was quiet.

(Remarkable Providences, Chapter V, 156-158)
\end{abstract}

Other stories in Mather's work are very similar, and recount numerous instances of possession, witchcraft, and malevolent magic. Why is it that a minister of a Reformed Church devoted so much of his intellectual energy to compiling tales that, according to the very same Church he was the minister of, were superstitious? If the Reformation fashioned itself as doctrinally pure, theologically correct in the interpretation of the word of God, non-idolatrous, and non-superstitious, why did many believe in magic, or possessed houses, objects, or people? Robert Scribner argued that while the religious doctrines of particular groups of Protestants present the Reformation as a break with pre-Reformation 'superstition', closer scrutiny of "actual religious practice of ordinary people" proves that "Protestantism did not represent, for the popular mind at least, a major dramatic paradigm shift from a sacramental to a secularized world" (as quoted in Hamilton \& Spicer 2005: 19). Alexandra Walsham in her revised outline of the 
Weberian disenchantment theory ${ }^{2}$ likewise suggested that not only were there limits to its sway in the sixteenth and seventeenth century, but that "the period to around 1650 witnessed a partial and temporary intensification of the assumptions that underpinned the late medieval sacramental universe". She also pointed out that the study of pre-Reformation religion and culture is crucial to the understanding of early modernity (Walsham 2008: 499-500). Scribner, Walsham, and many other Reformation scholars focused their studies of 'disenchantment' on analyses of sacraments and doctrines and their functioning within communities of believers which, as Eamon Duffy (1992) proved, did not wish to be rid of their "traditional religion". However, these investigations rarely went beyond the study of sacramentalism. I thus wish to examine how the influence of religion and the resonance of a pre-Reformation culture of faith reinforced popular belief in post-Reformation England, outside of the realm of doctrinal and sacramental religion. ${ }^{3}$ In order to do so I will outline how pre- and post-Reformation texts approached two areas of popular belief: medicinal magic, and the nature of objects and words. My aim is to reconsider the complex question of post-Reformation popular belief in England in relation to religion, and to investigate the extent to which it was influenced by an inherited popular tradition, religion-driven reasoning and practice, and recurring aspects of 'superstition'. 4

2 According to a theory by Max Weber, the Reformation released the world from the shackles of superstition, bringing about the scientific revolution, the secularization of life, and a gradual decline of belief in magic, called the "disenchantment of the world". Weber's main premise was that with the advent of Protestantism and the break with Roman Catholicism, the human mind was freed to explore its qualities of reason, common sense, and rational thinking, and that the spirit of Protestantism was the nucleus of the newly born modernity. Much of recent scholarship has, of course, since contested Weber's claim.

3 Inasmuch as that is possible, of course. I do not, in other words, wish to study such subjects as the Eucharist, Corpus Christi, ritualism of the Mass and worship, transubstantiation, justification, election, predestination, or the sacraments. For more on these subjects see, e.g., Miri Rubin, Corpus Christi: The Eucharist in late medieval culture (1991); Robyn Malo, Relics and writing in late medieval England (2013); R. N. Swanson, Indulgences in late medieval England: Passports to paradise? (2007); or Eamon Duffy, Stripping of the altars (1992).

4 Because my aim is to focus on continuities and the persistence of certain trends I do not wish to linger on demarcations of when the late medieval period ends and the early modern begins in England (especially since the Reformation is no longer considered to be such a caesura). For more on the unproductive nature of dividing the late medieval and early modern, see, for instance, the introduction to Brian Cummings' and Joseph Simmons' Cultural reformations (2011). See also a discussion in Michael Bailey's Fearful spirits, reasoned follies: The boundaries of superstition in late medieval Europe (2013: 236), in which he argues that when the boundaries between science and magic disappear, so do those between the early modern and the medieval. 


\section{Superstition, reason, and belief in Early Modern England}

Even though Protestants were self-proclaimed enemies of superstition, popular belief and Protestantism were not at all incongruous. In fact, pre- and postReformation clergy shared a dislike of "rival magical practitioners and the popular use of remedies outside of the church's control", and such concerns of the Protestants, along with their "efforts to use both courts and preaching to weaken its rivals" were "a common thread linking the medieval and Reformation period" (Barry 1996: 19). In other words, superstition was an extremely relative word. Religious policy and practice of the Reformation helped create a version of Protestant religious identity that accommodated popular belief by refashioning such belief in two ways. First, selected aspects of popular belief were redefined as a component of Roman Catholicism that needed to be condemned, selectively ascribing superstitious qualities to, for instance, such practices as making the sign of the cross during baptism. Then, other aspects of popular belief were attributed to Protestantism, or were pronounced as congruous with a Protestant culture of belief, the relic-like importance of the Bible, the upgraded concept of sainthood, or the intensified belief in devils, demons, and witches as a few examples. In the words of P. G. Maxwell-Stuart (2002: 170), in "various types of Protestantism, official disapproval of magical beliefs and operations had had little practical effect, and people continued to react and behave in ways which equally disparate Catholic communities would not have found in the least odd or confessionally peculiar. .... Examples of similarity between Catholics and Protestants in relation to magic are almost too numerous".

Through this strategy of incorporation, Protestantism in England accommodated aspects of 'superstition' that were formed at the intersection of religion, medicine, the supernatural, and magic, and allowed for the emergence of a new culture of the supernatural in sixteenth- and early seventeenth-century England. The concepts which I will focus on are magic and medicine. They offer an interesting study of interrelation and shared conceptual nuclei. The core notion in discussing these interrelations in Early Modern England, though, should be not that of secularization, re-enchantment, or a decline in superstition, but that of religion. It was the organizing principle of life, and was, at the same time, a sum of its components. Since religion requires belief on the one hand, and specialist knowledge on the other, it is the origin of both the concept of magic and science (including reason and medicine) (Kieckhefer 1989: 80, 140-142). ${ }^{5}$ Demanding of its believers (relatively) unconditional acceptance of truths that cannot be confirmed or debunked empirically, religion also proposes empiricism as a part of its own system and a method of its confirmation, thus becoming a thing in

$5 \quad$ See also Kieckhefer's European witch trials (1976); Forbidden rites (1997). 
itself and of itself. This preconditions a mind frame which seeks answers to spiritual questions along specific paths that evade a scientific definition in the sense of science as we understand it today, but which do fit into the understanding of science as it was construed in relation to religion in early modernity. In other words, people used to living in a religious culture were preconditioned, and trained, to live in a culture of belief which conveyed spiritual and supernatural truths as incontestable outside of the realm of that culture's existence and the reality it created. Belief was true because God was true, and the supernatural existed, because devils and demons existed. The difference between religion and the supernatural in pre- and post-Reformation England was thus not one of kind but degree: the line was demarcated between belief and practices that belonged and the ones that did not belong to the beliefs and practices of Christianity, and the condemned 'superstition' was not considered unrealistic, irrational, or unreasonable, but rather dangerous, misleading, sinful, or heterodox.

Religious societies and cultures between the fourteenth and the early seventeenth century in England shared an understanding of the supernatural as a part of faith because their notion of reason not only allowed for such a view, but encouraged it. The concept of reason in its meaning defined by the Enlightenment, of thought freed from religion and superstition, not only was not even near its conception in Early Modern England, but was incongruous with the mentalities of its people. For fourteenth-century thinkers reason was the natural, God-given faculty of the mind to rule the senses, but could not be applied to understanding God, because it was insufficient to grasp the full glory of creation. Edward Grant (2001: 285) suggested that medieval theologians believed the Christian faith was based upon revealed truths that were, in the end, beyond the scope of reason, because human reason was corrupted after the Fall. Early Modern Protestants were of exactly the same opinion. Robert Bolton, for instance, claimed that

[i]f a man looke upon GODS wayes onely with the eye of Reason they are foolishnesse to him; and sure if a man looke upon GODS Word and Workes through the false glasse of worldly wisedome, he cannot but imagine the thing promised.

(A Cordiall for Christians in the Time of Affliction, page unnumbered)

Peter Sterry likewise was of the opinion that

to seek out spirituall things by the sent and sagacity of reason; were to plough with an Oxe and an Asse. Sensus non fallitur circa proprium objectum, Sense is not deceived in judging of its own proper object. If sense and reason make no other report but this; This is the state of things, according to our principles: this is the appearance of things to us: Sense and reason may be admitted for true witnesses. But if they will be wise beyond what is written in their book, and say: This is the 
only, absolute, true appearance of things; because this is the appearance which things make to us. Now sense and reason become blind guides, and will lead you into the ditch: 1 Cor. 2.12. Spirituall things are spiritually discern'd. By proportion: sensuall things are sensually discern'd: rationall things are rationally discern'd. You cannot reach the things of reason by the hand of sense, though it be stretch't out like Jeroboam's towards the Prophet. You cannot understand spirituall things Rationally; that is, upon the grounds of Reason.

(The Spirits Conviction of Sinne, 12)

The 'age of reason' did begin in the late Middle Ages (Grant 2001: 285), with its praise of reason as a gift from God and the inseparable connection between reason and God, or reason and spirit, but it did not mean the same it meant to eighteenthcentury thinkers. Sterry and other Protestants, in turn, did argue that reason and spirit were separate, but they also argued for the superiority of spirit over reason, and were thus still under the influence of the conviction that religion, God, and spirituality were not so much different from reason, as that they simply could not be comprehended by reason, because it was faulty, corrupt, and impotent in understanding God's plan. Only in the eighteenth century was reason used to challenge the supremacy of the truths of revelation. Neither pre- nor postReformation writers did so, ${ }^{6}$ choosing instead to think of reason as a tool of God's plan, marrying it with religion, belief, and religious practice. ${ }^{7}$

Such an approach to belief and reason allowed for the formation of a specific kind of thinking - religious thinking. The underlying reasoning methods for scholars, theologians, and doctors in the fourteenth through the early seventeenth century were scholasticism, natural philosophy, and analytical theology, taught at universities and disseminated in seminaries, law schools, and medical colleges (Wallis 2010: 191). These methods of thinking, founded on religious belief, influenced the way both theology and medicine were practiced, and it was theology and medicine, in turn, which rehearsed and disseminated ideas about magic by acknowledging the existence of the mysterious, inexplicable, and incomprehensible in many of their practices. Of course, religion never meant

6 John Morgan in his Godly learning: Puritan approaches to reason (1988) persuasively argues a similar case.

7 See for instance texts such as A Discourse of the Repugnancy of Sin to the Principles of Universal Reason Being a Dissuasive From a Sinful Life From Principles of Common Wisdom Currant Amongst All Mankind, Save Onely in the Concerns of Their Souls, London: Printed and are to be sold by Edward Millington ... and William Abington ... (1679) in Houghton Library, where the argumentation expertly proves that a reasonable person is Christian, a believer in God, and does not sin, because reason can only coexist with pure (or attempting to be pure) spirit. It is interesting to compare this to some pre-Reformation texts, such as the c. 1430 Errorers Gazariorum, in which the Devil that appears to the heretics is called "the enemy of all rational creatures" (as translated and quoted in Michael Bailey, Battling demons: Witchcraft, heresy, and reform in the Late Middle Ages, 2003: 1). 
condoning magic, and superstition was always shunned by clergymen. But while criticism of superstition is traditionally conceived to belong to Protestant rhetoric, it was widespread before the Reformation as well, as a natural attempt to structure and control popular imagination by the established church. The strategy, however, was not to eradicate popular belief, but to order, or obliterate, only certain kinds of popular belief, chosen on the basis of ideological, political, social, or cultural policies and agendas of a given church.

For instance, John Mirk's Festial (c. 1380-1400) used ghost narratives not in order to ridicule or banish belief in ghosts, but to turn them into moral exemplars and argue, among other things, that no murder went unpunished. In one of Mirk's stories, a man killed a travelling merchant for money (persuaded to commit the evil deed by his concubine), but as he walked past the grave of the person he killed: "pe graue opened, and be cors sate vp, ... and sayde: 'Lorde pat art ryghtwys juge, pou wreke me apon pis man pat hape pus falsly slayne me for my trew catayle.' And perwyth come a voyce from Heuen and sayde: 'Thys day prytty wyntyr, pou shalt haue vengeans' (Festial, 88). And so it happened: the murderer and his concubine died, to the day, thirty years later. The story thus serves a moralizing purpose, and illustrates how orthodox church practices (preaching, in this case) made use of popular belief to their own (pastoral) benefit. Likewise, Cotton Mather's Wonders of the Invisible World (1693) narrated the following tale:

[i]t has been a frequent thing for the Bewitched People to be entertained with
Apparitions of Ghosts of Murdered People, ... these Ghosts do always affright the
Beholders more than all the other spectral Representations; and when they exhibit
themselves, they cry out, of being Murthered by the Witch-crafts or other Violences
of the Persons who are then in Spectre present. It is further considered, that once or
twice, these Apparitions have been seen by others, at the very same time they have
shewn themselves to the Bewitched; and seldom have there been these Apparitions,
but when something unusual or suspected, have attended the Death of the Party thus
Appearing. Some that have been accused by these Apparitions accosting of the
Bewitched People, who had never heard a word of any such Persons ever being in
the World, have upon a fair Examination, freely and fully confessed the Murthers
of those very Persons, altho' these also did not know how the Apparitions had
complained of them.

(Wonders of the Invisible World, 66)

Mather describes trials in which the accused allegedly bewitched others into seeing apparitions, which then forced them to confess to murder. He, therefore, also makes use of popular belief in ghosts ${ }^{8}$ to convey a warning to sinners that all sins are punished in the end. Both Mather and Mirk use their narratives to

8 For a detailed study of early modern belief in ghosts (and the role of the legacy of Purgatory in the Protestant belief in ghosts) see Peter Marshall, Mother Leakey and the bishop: A ghost story (2007). 
reconcile popular belief with Christianity, making supernatural agents the bearers, or inciters, of truth and the word of God.

A similar method of turning superstition into a tool of orthodoxy is observable in the widely known and recognized Protestant (especially Puritan) detestation of everything Roman Catholic. For the Puritans, the criticism of Roman Catholicism as superstitious was part of their self-fashioning and self-legitimizing strategies. By presenting some of the sacraments and the Eucharist as magic (Bailey 2003: 236) the Puritans showed themselves to be purer, more reasonable, and more accurate in terms of doctrine and practice. At the same time, of course, they retained the Lord's Supper as a cleaned up version of the Eucharist (and the controversy with the Eucharist and transubstantiation was old news in England at least since the time of Wycliffe), and baptism. Such self-fashioning, as Roman Catholicism's 'Other', gave Puritans relative freedom to apply other aspects of popular belief, such as belief in evil spirits or witchcraft, into their own practice. Presenting themselves as more knowledgeable about what was proper and improper in belief and worship, they legitimized many of their doctrinal and theological choices either as their own (when in fact they were not, like iconoclasm), or as 'proper', as was the case with confession. Theoretically, confession was to be made only to God (or in public) but according to Calvin's revised edition of his Institutes (1599), and in the practice of many English Protestants, the faithful were actually strongly advised to confess in private, to a clergyman. ${ }^{9}$ Through the same mechanism they could, for instance, also legitimize their continued (though modified) use of exorcisms. The postReformation condemnation of superstition had also much to do with religious policy in a time when different Protestant groups propagated various approaches to aspects of doctrine and practice (such as prayers for the dead, ${ }^{10}$ the proper conducting of funerals, or to the propriety of clerical vestments), and served as a differentiating and legitimizing strategy also between Protestant denominations. Superstition, therefore, referred only to very specific beliefs and practices, selected to be labelled as superstition according to the agenda of those who were doing the labelling, and aided strategies of identification and moral management.

Post-Reformation communities, therefore, did not become more secularized, or less 'superstitious'. The formerly singular current of belief, with an established church, doctrine and popular belief as its overlapping branches, became divided into many currents, often not that different, but equally often disparate from one another. Multiple policies and agendas, for instance of the monarchy, or episcopal

9 "We see that ministers, to assure our consciences of the forgiveness of sins, are appointed to be the witnesses and sponsors of it, so that they are themselves said to forgive sins and loose souls", John Calvin, Institutes of the Christian Religion, 1599, III 4:12.

10 See Peter Marshall's Belief and the dead in Reformation England (2002). 
and non-episcopal preachers, Presbyterians, Catholics, or parish priests, further diversified accepted currents of belief, and sometimes resulted in milestone departures from the old tradition (e.g., the ruler of England as head of Church). But, these various branches remained united in their approaches to the supernatural, because "Protestants, for all their cries of superstition against Catholics, did not hesitate to accommodate in both their thinking and in their practice (...) [the] preternatural or supernatural". The diversification of early modern belief thus stemmed as much from change as it did from the reappearance or perseverance of pre-Reformation beliefs. The puritans, for instance, according to a seminal study by Richard Godbeer

[f]or all their determination to break with the "superstitions" of the past, ... were just as convinced as other English men and women that the universe was an enchanted place ... . Puritans, both clerical and lay, inhabited a world of "wonders" ... . All events that seemed to interrupt the natural order were believed to carry supernatural significance, although the specific meaning of a given wonder was usually mysterious. The lore of wonders that pervaded seventeenth-century English culture ... derived from folklore, classical meteorology, apocalyptic prophecy, and natural philosophy. Transmitted both orally and through printed matter, this hodgepodge of traditions ... [and] [t] he open-ended nature of wonder lore enabled people of different faiths to appropriate wonders for their own use. .... Puritans were eager to record and digest all supernatural incidents.

(Godbeer 1992: 56)

In other words, the Reformation augmented rather than diluted popular belief by offering not one, but many different ways one could believe in demons or witches, and pray, worship, hope, or despair. It took almost another century after the 1534 Act of Supremacy for England to go through a religious change thorough enough for many scholars to consider England a truly Protestant country. ${ }^{11}$ Until as late as the ascension of James I England was a country of religious turmoil, shaky and sometimes short-lived consensuses, and of a peculiar combination of the old and the new, pre- and post-Reformation traditions. Changes that started in the 1370s with the works of John Wycliffe, underscored by Henry VIII's break with Rome,

11 There are multiple accounts of the early Reformation in England, which ultimately fall into two categories. The traditional one argues that the Reformation in England was a long-sought ascent of the Renaissance, release from the terror and taint of Catholicism. A revision of this is offered in more recent scholarship, such as Duffy's The stripping of the altars (1992) or Christopher Haigh's English reformations: Religion, politics and society under the Tudors (1993), which present the sixteenth century Reformation as a largely political movement significantly unpopular with the majority of the English society. Others within this revisionist movement insisted on various timeframes of the Reformation. Peter Marshall (2012), for instance, suggests it to span 1480-1642. Christopher Hill (1961), when discussing the Puritans in the early seventeenth century, suggests that the early modern period in England only began in 1604, with the ascension of James I, and so the Middle Ages ended in 1603 with the death of Elizabeth I. 
step by step turned belief in England into a complex, yet accommodating structure in which, quite miraculously, aspects of the pre-Reformation tradition, innovation, religious controversy, and conformism could all coexist, though not without tension. This ambience of dynamic religious development, particular to England, with all its often conflicting currents, had one recurring trait: it placed focus on spiritual interiority. Of course, late medieval devotional practice likewise encouraged and fostered internal spirituality and a personal relationship with the divine ${ }^{12}$, and there is no doubt that both orthodox and heterodox (mainly Lollard) pastoral care and private devotion, as well as texts, inculcated individual spirituality. People read devotional texts and excerpts of the Bible at home, ${ }^{13}$ meditated on the Passion and their own sinfulness, attended services, and prayed at home.

After the Reformation the intensity of such practices, as well as some of their details were influenced by alterations in doctrine (e.g., the different form of services gave rise to different kinds of sermons), and the practicalities of text availability (the Bible gradually became translated into English in full, pocket Bibles emerged as cherished possessions of some Christians, etc). ${ }^{14}$ These changes, however, though noticeable to modern scholars and certainly perceivable to sixteenth- and seventeenth-century laity, differed in detail rather than principle: people still wanted to read, and did read, devotional texts, still meditated on their own sinfulness and on Christ's Passion, prayed at home, went to services, and were actively pursuing the ideals of spiritual interiority, well established by the early modern period. ${ }^{15}$ Similarities are most clearly visible in

12 See Jessica Brantley, Reading in the wilderness: Private devotion and public performance in late medieval England (2007), for a study of late medieval private devotion, and Jennifer Bryan, Looking inward: Devotional reading and the private self in late medieval England (2008), for more on late medieval spiritual interiority and the importance of personal religious experiences in the religious landscape of late medieval England.

13 For a comprehensive history of translations of the Bible into English, see David Lawton's "Englishing the Bible, 1066-1549", in David Wallace (ed.), The Cambridge history of medieval English literature (2002).

14 For more on this complex subject see, for instance, Jessica Martin \& Alec Ryrie (eds.), Private and domestic devotion in Early Modern Britain (2016), especially chapters by Ian Green, Erica Longfellow, Jessica Martin, Kate Narveson, Jeremy Schildt, and Alison Shell; or Mary Hampson Patterson, Domesticating the Reformation: Protestant best-sellers, private devotion, and the revolution of English piety (2007).

15 The subject of changes in post-Reformation private devotion is a broad one and cannot be pursued here in full. The reader is invited to refer to a number of volumes written on this topic, e.g., the classic Stephen Ozment, The age of reform 1250-1550 (1980); Charles Trinkhaus \& Heiko Oberman (eds.), The pursuit of holiness in late medieval and Renaissance religion (1974); Berndt Hamm, The reformation of faith in the context of late medieval theology and piety (2004); or the more recent Carlos Eire, Reformations: The early modern world, 1450-1650 (2016) with a useful bibliography on the subject throughout; Peter Marshall, Reformation England 1480-1642 (2012); Christopher Harper-Bill, The pre-Reformation church in England 1400-1530 (2014); Robert 
Anglicanism, especially before 1603, and then under Latimer and Laud, in their worship and pastoral practice. ${ }^{16}$ The largest, and most general, difference between the pre- and post-Reformation devotional landscape that stands out among many similarities is the quantitative increase in individual piety practices (partially due to a large increase in the production and printing of devotional manuals) ${ }^{17}$ as well as in a perceivable surge in the intensity of a certain kind of internal spiritual sensations, namely those related to fear. While a lot can be, and has been, said about how belief in Purgatory kept the pre-Reformation faithful in check, ${ }^{18}$ 'fearful' piety (i.e., spirituality and piety infused with fear) peaked after the Reformation, due to (by now) well-known reasons: the abolition of traditional sacrament of penance, predestination, uncertainty about election, and the rejection of Purgatory. All these elements of change in private devotion, while well-recognized, have recently also been discussed as less obvious causes of friction for the early modern faithful. ${ }^{19}$ In fact, a case can be made that due to the extreme diversity of post-Reformation religiosity in England many of these aspects of change were much less grave for the post-1534 spiritual laity than it seems. The controversy over, and partial rejection of, pre-Reformation religious imagery is a much better candidate to be considered the reason for changes in the landscape of spiritual interiority of early modern Christians.

Lutton, Lollardy and orthodox religion in pre-Reformation England (2006). For more on how preReformation religious literature was received in post-Reformation England see, for instance, Anne Hudson, The premature Reformation. Wycliffite texts and lollard history (1988), especially chapters 9 and 10; and Anne Hudson, Lollards and their books (1985), especially chapter 15; or Christopher Haigh, English reformations: Religion, politics, and society under the Tudors (1993); and of course Eamon Duffy, The stripping of the altars (1992).

16 See, for instance, Peter Lake, Moderate Puritans and the Elizabethan church (1982), Christopher Haigh (ed.), The English Reformation revisited (1987), and Christopher Haigh, English reformations: Religion, politics, and society under the Tudors (1993); Chapter 8 in Patrick Collinson, The Reformation: A history (2004); or Eamon Duffy's chapter "Continuity and divergence in Tudor religion" in R. N. Swanson (ed.), Unity and diversity in the Church (1996).

17 This was related to the fluctuating numbers of literate laypeople in England (the often proposed "rise" in literacy after the Reformation is a simplification; see Michael van Cleave Alexander, The growth of English education, 1348-1648 (1990) for more on this subject.

18 E.g., Peter Marshall, "Fear, purgatory, and polemic in Reformation England" in William G. Naphy \& Penny Roberts (eds.), Fear in early modern society (1997).

19 See, e.g., David Como, "Puritans, predestination and the construction of orthodoxy in early seventeenth-century England”, in Peter Lake \& Michael Questier (eds.), Conformity and orthodoxy in the English Church, c.1560-1660 (2000); Abigail Firey (ed.), A new history of penance (2008), especially chapters by Henry Ansgar Kelly, Wietse de Boer, and Ronald K. Rittgers; Peter A. Dykema, "Handbooks for pastors: Late medieval manuals for parish priests and Conrad Porta's Pastorale Lutheri (1582)" in Robert J. Bast \& Andrew C. Gow (eds.), Continuity and change: The harvest of late medieval and Reformation history (2000); and Michael Milway, "Forgotten bestsellers from the dawn of the Reformation" ibid. (2000). 
Doctrinal issues with religious imagery as idolatrous and waves of iconoclasm left a certain gap in personal maps of devotion. Sin, the Devil, or demons, easy to conceptualize in the past, were likewise easy to fight, because as many texts, like Walter Hilton's Scale of Perfection (c. 1380) taught, an enemy objectified is an enemy conquered. After the Reformation evil could no longer be seen and tackled this easily ${ }^{20}$ and this augmented devotional fear: of evil that could no longer be recognized at a glance, of damnation, devils which no longer looked familiar, and through that, as a consequence, of witchcraft, demons, and their invisible omnipresence (Bailey 2003: 233). Images could no longer be laymen's books, as John Mirk proposed (c. 1380-1400), and evil that could not be seen left the soul defenceless. At the same time, the increase in pastoral and devotional texts that discussed the threat of the Devil and his role both as the enemy of God and a tool of His judgement also contributed to the increase of piety lined with devotional fear. There was, thus, through the post-Reformation focus on interiority, an increased need to externalize and objectify evil, and because it could not happen through the less and less familiar traditional venue of religious imagery (which was not, of course, entirely forgotten or forbidden, but was a source of more tension than comfort), it was channelled differently, through a surge in selected areas of popular belief..$^{21}$ This could be accomplished because in popular belief new rules of devotion did not apply. Changes in orthodoxy in England after 1534, in other words, encouraged many to turn to beliefs that were familiar, did not belong to the mainstream of religion that was undergoing a substantial reconstruction, and were thus more constant, an anchor of tradition and peace. While sacraments, vestments, worship, theology, and priesthood were no longer stable reflections of one creed, beliefs in the supernatural, magic, witches, or holy properties of herbs lived on, as stable in their plurality as before, with rhetoric of superstition voiced against them well-known and familiar, and thus easily ignored.

Examining aspects of popular belief it is therefore possible to trace, from a variety of sources, a rich tradition of an enchanted world that developed across time, but slightly off the beaten track of changes that occurred between pre- and post-Reformation England. It is important to see popular belief as an inseparable part of England's culture of belief between the fourteenth and the seventeenth century, because it comprised an integral part of England's religion, including its orthodox, conforming as well as more radical manifestations. The diversity of its influence will be outlined below. By focusing on two aspects of the supernatural,

20 Religious images, however, of course did not disappear from England after the Reformation. See Duffy's Stripping of the altars (1992) for more on the subject.

21 See also Alan Charles Kors \& Erin Peters, Witchcraft in Europe, 400-1700: A documentary history (2001) and Alison Coudert, Religion, magic, and science in Early Modern Europe and America (2011), chapters 1-4, for a discussion of how changes in the perception of Satan and evil fuelled a surge in devotional fear, fear of witchcraft, and responses to that fear. 
magic and medicine, and two ways in which they were seen (objects) and heard (words), let us now turn to tracing some of the intricacies of the role of the supernatural in constructing a culture of belief specific to England both before and after the Reformation, to see how certain elements of popular belief reemerged in Protestantism.

\section{Medicinal magic and religion: leprosy}

Some practices are performances of culture rather than illustrations of actual and literal belief: it is possible to make the sign of the cross during prayer through adherence to a convention rather than through believing that it somehow catches God's attention, as it is possible to treat a prayer for health during time of sickness as part of the healing process, and God and the Holy Spirit as healers who act through physicians, not as a request for a miracle. Yet at the same time both these and other practices did balance on the verge of supernatural belief, because there was a cause and effect relationship that many observed between a prayer and a blessing, a sin and a curse, or sin and sickness. Certain objects and words, likewise, did carry both a spiritual and a magical meaning for both pre-Reformation and postReformation Christians, and this can be seen in the complex relationship between medicine and magic, and their relation to religion and belief. Belief in magic is an umbrella term for a complex phenomenon that conceptually and cognitively encompasses the will to understand the world, human desires and needs, an acknowledgement of the existence of the supernatural and, perhaps as closest to everyday life, adherence to religion (Saunders 2010: 5). Magic is a proto-science, "drawing on the deep forces of the universe", and is in that tied to medicine, which was both an academic discipline (natural philosophy, the search for knowledge about the nature and origin of things, reasons for their existence), and a practical craft acquired through experience that demanded of its practitioners specialist knowledge and skill. Quoting Faith Wallis, "medicine is a thread tightly woven into the intricate tapestry of assumptions, symbols, narratives, ideas, and ideologies that constitutes a culture" (Wallis 2010: xix), and the same can be said about the understanding of 'magic' in Early Modern England. Practitioners of medicine needed to know the nature of the objects, herbs, and treatments they used and their relation to the main body of medicine. Likewise, practitioners of 'magic' were required to know the same about the objects and words they used, their relation to the main tenets of the system (whatever the system was), the good and evil use of rituals, and their benefits and risks. All these traits, of course, can also be found in the primary, ultimate, and prevalent belief system: religion. Practitioners of religion likewise had to possess specialized knowledge: of doctrines, rituals, words, and objects used in worship and practice, and their relation to the larger body of religion. Specialist knowledge, therefore, is what brings religion, magic, and 
medicine together. According to Corinne Saunders, "religious rituals may be compared to magical rituals, as medical rituals may also be. The decisive affiliation of a given ritual, its magical, religious, or medicinal character, thus depends on the purpose, nature, and perception of the ritual by those who enact or experience it, and may readily become blurred" (Saunders 2010: 10).

Magic, medicine, and religion, then, through the cognitive qualities of belief, were tied together in everyday lives of pre- and post-Reformation communities, as much in their performance as outcomes. If a physician implemented prayer into his medicinal practice and the patient was cured the cure and physician were divinely approved; if a woman was in conflict with another woman, performed angry 'cursing' gestures or incanted curses against her adversary who later became ill or experienced misfortune, the interpretation of this illness or misfortune attributed them to the witchcraft of the enactor of the curses. Multiple examples of trials listed by Kieckhefer (1989) dealt with accusations of causing harm and illness by an individual or a group through the use of harmful magic. ${ }^{22}$ Early modern people, therefore, saw a clear connection between magic and bodily health, particularly between dark magic and bodily sickness (Kieckhefer 1989: 191), ${ }^{23}$ and religion highlighted and confirmed the relationship between the body and magic. Popular interest in nature and its forces, in turn, combined with the social importance and practice of medicine, folk legends, and religious instruction, underscored the understanding of medicine as a version of magic, if not for its practitioners than for its recipients (Saunders 2008: 180).

Such 'medicinal magic' with a strong religious agenda was a frequent motif in many texts. Textual renderings of leprosy, for example, carried multiple meanings that generally fall into two categories. First, leprosy was considered from a religious point of view and could signify a number of moral ailments: it could be God's punishment for sin (especially sins related to lust), but it could also be the result of a curse (Murdoch 2000: 102). Finally, it often served as an allegory to convey opinions about morality, of an individual or humanity in general, and was connected to Christ and the Passion. Second, leprosy from a medical point of view could signify a number of medical conditions, including the plague, pox, and syphilis, the latter due to the presumed connection between leprosy and sexuality (as in, e.g., the 1605 History of the tryall of cheualry) on the basis of which lust, lechery, or a 'lustful disposition' led either to contracting leprosy by contagion, or

22 See Kieckhefer (1989: 187-194). There was a surge in number and an increase in the harshness of witchcraft trials after the fourteenth century.

23 This was, in turn, connected to the relationship between witchcraft and heresy. Pope Alexander II's suggestion that magic should be prosecuted by inquisitors when it smacks of heresy contributed to the emergence of an understanding of witchcraft as a version of heresy, later further reinforced by the 1401 De heretico comburendo, a stepping stone in the prosecution of witchcraft in the early modern period. 
as punishment from God. The medical understanding of leprosy was thus connected to its religious understanding, all the more so that leprosy was also frequently featured as a shorthand for heresy, as a disease of the soul.

Pre-Reformation texts used leprosy in all these meanings, from it being a result of $\sin$ (e.g., in the c. 1430 Pricke of Conscience), through it being an illness (sometimes confused with other illnesses), to its connections to Christ. Thomas Malory's 1485 Morte D'Arthur, for instance, tells the story of Galahad, Bors, and Perceval and his sister who venture upon a castle which, as they are told, has a certain custom that needs to be obeyed: any maiden that enters it needs to give a plate-full of blood from her right arm to the knights of the castle. Of course, Galahad and Perceval refuse and a fight ensues, but it is later explained to them that the custom is not an evil scheme, but a way of helping a certain lady. The story then unfolds as follows:

[t]her is in this Castel a gentylwoman whiche we and this castel is hers and many
other. Soo it befelle many yeres agone there fylle vpon her a maladye, and whanne
she had layne a grete whyle she felle vnto a mesel and of no leche she coude haue
no remedy. But at the last an old man sayd and she myght haue a dysshe ful of blood
of a mayde and a clene vyrgyn in wylle and in werke, and a kynges doughter that
blood shold be her hele, and for to anoynte her with alle ... . Now said Percyuals
sister fayr knystes I see wel pt this gentylwoman is but dede. Certes sayd Galahad
and ye blede soo moche ye maye dye. Truly sayd she, and I dye for to hele her. I
shal gete me grete worship and sowles helthe and worshyp to my lygnage, and better
is one harme than tweyn. And therfor ther shall be no more batail but to morne I
shall yelde yow your customme of this castel, and thenne there was grete Ioye more
than there was to fore.... \& on the morne they herd masse, and sir Percyuals sister
bad brynge forth the seke lady, so she was the whiche was euylle at ease. Thenne
sayd she who shall lete me blood. Soo one came forth and lete her blood and she
bled soo moche that the dysshe was ful. Thenne she lyfte vp her hand and blessid
her. And thenne she said to the lady, Madame I am come to the dethe for to make
yow hole, for goddes loue prayeth for me. With that she felle in a swoune. Thenne
Galahad and his two felawes starte vp to her and lyfte her vp and staunched her but
she had bled soo moche that she myght not lyue. Thenne she sayd whan she was
awaked fayre broder Percyual I dye for the helynge of this lady.... Thenne asked
she her saueour and as soone as she had receyued hit the soule departed from the
body. Soo the same daye was the lady helyd whan she was enoynted with alle. (Morte D'Arthur, Book Seventeen: Syre Galahad, Capitulum xj, 706)

The lady of the castle had leprosy ("mesel"), which as many works on medicine ascertained, had no cure. According to Bartholomeus Anglicus in his famous De proprietatibus rerum: ${ }^{24}$ "Lepra bréedeth in mans body: but howsoeuer it be

24 Originally written in the thirteenth century, this text was very popular among early modern audiences; Bartholomeus was included in John Leland's 1552 catalogue of important and esteemed English writers. The text was first printed in 1495, but was very popular before that, with a large number of manuscript versions, and after Caxton's first edition it went through a number of re- 
gendered, vnneth it is curable, but by the helpe of God, if it bée confirmed" (Batman vppon Bartholome his booke De proprietatibus rerum [1582], Book Seven 'Of Lepra Meseltie', cap. 65). Indeed, there was no known cure for leprosy until as late as the twentieth century. Perceval's sister, then, sacrificed her life for a victim of leprosy, even though lepers were treated as the lowest of the low in society, outcasts rarely allowed inside cities with separate areas, leprosariums, and colonies, such as Spinalonga, designated for them, ${ }^{25}$ usually shunned from company as impure, or cursed. And yet as the reasons for leprosy were understood to be religious (sin) as much as physical (lecherous disposition), so attempts at its curing were both religious and physical. Leper houses and colonies were organized according to religious rules, often as quasi-orders, with groups such as the Order of St Lazarus of Jerusalem in England founded to help cure leprosy by prayer. Showing charity to lepers was thus a sign of highest virtue of an exemplary Christian, imitating Christ who took pity on lepers. Malory's account reinforces the conviction that leprosy could be cured only by methods that stemmed from Christian charity and virtue: sacrifice, purity, love. At the same time, Malory's story mentions also the widespread belief in the physical cure for leprosy, blood, dramatized for the sake of the story as specifically innocent blood. The belief that blood, either the leper's, a healthy person's, or that of an animal (such as a hare), added to ointments or drinks could cure the early stages of the sickness was part of popular (medical) belief. Similar narratives suggesting innocent blood as a cure for leprosy can be found in other romances such as Jaufré (c. 1220?), Amys and Amiloun (c. 1330-1400), as well as in Piers Plowman (c. 1370-1390), Gower's (c. 1390) Confessio Amantis, ${ }^{26}$ and many other texts. However, all these accounts very rarely prescribed blood as a real cure. It was, instead, an allegorical, rather than an actual cure, and had more to do with sacrifice, humility, purity, and virtue, ${ }^{27}$ as well as faith, and Christ.

Malory's narrative of leprosy ${ }^{28}$ is a clear reference to the story of Emperor Constantine. Baptized only on his deathbed, the emperor that introduced

prints until 1600. After that time it remained an important source of reference to early modern writers and historians (Elizabeth Keen, Journey of a book: Bartholomew the Englishman and the properties of things, 2007: 1-6). For more on the history of this work, its editions, and the history of its importance to medieval and early modern audiences see Keen (2007) throughout.

25 For more see Ernest B. Gilman, Plague writing in Early Modern England (2009).

26 For more on this see Byron Lee Grigsby, Pestilence in medieval and Early Modern English literature (2004), chapters 3 and 4.

27 Although some stories used the theme of blood to further the blood libel against the Jews. See David Biale, Blood and belief: The circulation of a symbol between Jews and Christians (2007).

28 Malory himself took it from the Arthurian Vulgate Cycle, a thirteenth-century compendium of five prose works (which in turn were based on Chretien de Troyes's Conte du Graal and Robert de Boron's Joseph d'Arimathie, Merlin, and Perceval); Medieval Arthurian epic and romance: Eight new translations in William Kibler \& Barton Palmer (eds.), 2014: 235. 
Christianity to Rome through an edict decreeing tolerance towards Christians became the subject of a story repeated in many sources since the fourth century (including by Gower in his Confessio Amantis), in which through faith he is cured of leprosy. Constantine, according to most versions, became sick with leprosy and was advised to bathe in the blood of children as a cure. Just like in Malory, only innocent blood was considered able to save a leper. But, Constantine refused to massacre children, and through that compassion he was saved: Peter and Paul descended from heaven and told him that he could be cured through baptism, and indeed, when he became Christian his leprosy literally fell off him. ${ }^{29}$ In the end he was cured by innocent blood, but that of Christ. Likewise, in Malory's account only when Perceval's sister gave her blood willingly, through compassionate sacrifice, was the leprous lady cured. In both cases, innocent blood, sacrifice, and compassion refer to Christ and his crucifixion. Piers Plowman makes the connection between leprosy and Christ's blood clear: a leprous man is said to be so sick "[n]e no medicine under molde the man to hele brynge, Nother Faith ne fyn Hope, so festred aren his [leprous] woundes. Withoute the blod of a barn he beth nat ysaved, The whiche barn mote nedes be borne of a mayde, And with the blod of that barn enbaumed and ybaptised. ... Till he have eten al that barn and his blod drunken ... That his lycame shal lechen at the laste us alle" (C-text, ed. Elizabeth Salter \& Derek Pearsall, Book 14, 1l. 38-48, 152). Only baptism in the blood of Christ (i.e., Christian baptism) could wash away leprosy, as it did for Constantine, and as it would for other spiritual lepers. Christian symbolism thus perpetuated the connection between blood, leprosy, and medicine in popular belief, and belief in the mystical properties of pure (or impure) blood. Another popular though likewise mystical cure for leprosy was gold (as it was proposed for instance in the aforementioned De proprietatibus rerum). Gold as the purest, alchemically most difficult to obtain metal symbolized virtue, and a successful transmutation of gold indicated the virtue and purity of the alchemist. ${ }^{30}$ In other words, then, leprosy was a moral sickness and could only be cured by faith, sacrifice, and virtue.

After the Reformation leprosy also was viewed as punishment for sin. For instance, John Davies' Microcosmos (1605) stated that the senses were windows through which sin entered the body, particularly lechery, since leprosy was increasingly confused with syphilis in the early modern period (as it became more widespread) (Harris 1998: 27-28). Leprosy was also a frequently used symbol of moral corruption and decay, as a large number of preachers after the Reformation

29 For more on this, see Noel Lenski (ed.), The Cambridge companion to the age of Constantine (2006), especially "Introduction" (6-10); Samuel N. C. Lieu \& Dominic Montserrat, From Constantine to Julian: Pagan and Byzantine views; a source history (1996).

30 For more see Hereward Tilton, The quest for the phoenix: Spiritual alchemy and rosicrucianism in the work of count Michael Maier (1569-1622) (2003); and Gary Edson, Mysticism and alchemy through the ages: The quest for transformation (2012). 
talked about it as a spiritual disease, applying its imagery as a shorthand for sin and human corruption. For instance, the Puritan John Trapp wrote that:

[t]here are centuries of diseases lying in wait for mans precious life, but far more for
his soule. There is the rympany of pride, the dropsy of covetousnesse, the fever of
ambition, the frenzy of passion, the consumption of envy, the epilepsy of Apostacy,
the lethargy of security, the plague of discontent, \&c Now affliction is Gods
Catholicon, the crosse is the cure of them all. Gehezi tells the praises of his severe
master to King Iehoram. Whence some conjecture, that his leprosy made him cleare,
that his white forehead made him a white soule, that his disease cured him.
(Gods love-tokens, and the afflicted mans lessons brought to light, 27)

He also believed that "[a]n ignorant person is that Leper in Leviticus, his plague is in his head, he is utterly uncleane, and is therefore utterly to be excluded" (Theologia theologiae 1641: 206), and that when Christ was born "the Word was made flesh, Put himselfe into a lowsie leprous suite of ours, to expiate our pride and robbery, in reaching after the Deity, and to heale us of our spirituall leprosie; for ... if he had not assumed our flesh, he had not saved us. ... This is hell above ground, and aforehand. Affected ignorance is the leprosie in the head, which makes a man undoubtedly uncleane, and utterly to be excluded" ( $A$ brief commentary or exposition vpon the Gospel according to St John, 1646: 6, 17). Another Puritan minister, John Cotton, presiding over Anne Hutchinson's trial likened her opinions to gangrene and leprosy that "hath so infected the Churches that God knows when they will be cured" (1638). William Narne, likewise, in his 1630 Pearle of Prayer lamented that he had "great reason to lament the spirituall leprosie of mine inward man: ... I am vncleane: If the bodilie leprosie of Oziah, King of Iudah, caused him to bee cut off from the house of the LORD; ... may not my spirituall leprosie separate mee from the societie of CHRIST, from the communion of the Saincts, and depriue mee of an Heavenly Kingdome" (Pearle of Prayer, 158). Thomas Tymme wrote about heretics that they are lepers, dividing the contents of his A Plaine Discouerie of ten English Lepers (1592) into discussions of "the Schismatique, ... the Churchrobber, ... the Simoniac, ... the Hypocrite, ... the proud man, ... the Glutton, ... the Adulterer or Fornicator, ... the Couetous man, ... the Murtherer, ... the Murmurer". He wrote of 'lepers' as spiritual lepers, or sinners and heretics, which brings us back to the discourse of heresy as an illness caused by dark magic and witchcraft. The pre-Reformation conviction that "witches, no matter how they were defined, were heretics" (Broedel 2003: 122) found its new form in the post-Reformation belief that heretics or blasphemers, newly defined as anyone whose doctrinal convictions did not fit into the doctrinal 
convictions of whoever was in power, ${ }^{31}$ were equal to evildoers in league with the Devil, and were also guilty of either spiritual leprosy, or gangrene, as in various seventeenth-century 'heresiographies' such as Thomas Edwards' 1646 Gangraena, or a Discovery of many of the Errours, Heresies, Blasphemies, and Pernicious Practices. Diseases like leprosy and gangrene were good metaphors for spiritual sickness and decay, as they relied on the shared, and thus commonly understandable, notions of religion, magic (as witchcraft), and medicine.

Many post-Reformation references to leprosy differed from its pre-Reformation treatment in a number of ways. The equation of leprosy and lechery was infrequent (though definitely existed) before the Reformation, the Pricke of Conscience (c. 1430) being one of the very few texts that make such a connection directly (Grigsby 2004: 77). Although the relation between leprosy and various kinds of sin was perhaps implied and often mentioned (e.g., in medical works which prescribed sexual abstinence as a preventive measure against leprosy), it was postReformation authors that turned leprosy into a popular metaphor for sin in general, and it was them that applied it to narrate their opinions on moral decay of society (including their confessional opponents). Another difference lies in the more strictly religious context in which leprosy was used as a metaphor after the Reformation: the majority of texts narrate the story of Naaman and Gehazi as a Biblical source for their understanding of leprosy, and the discourse of leprosy as sin rarely features anywhere outside a sermon or a religious treatise. The references to leprosy (i.e., syphilis) as a consequence of lechery likewise feature much more often in post-Reformation texts. However, there are also two aspects of the discourse on leprosy that pre- and post-Reformation works share: their overwhelming conviction that it had a religious source, and thus should have a religious cure, and their focus on the redeeming properties of innocent blood, and the blood of Christ.

Many Protestants felt the need to highlight that leprosy was an illness related to the state of the soul, and were not happy with how little attention, in their view, was paid to its spiritual aspects. The primary Puritan concern with medicine, particularly with Galen, the ancient Greek father of experimental physiology, whose theories on anatomy were widely used by early modern doctors, was that not enough gravity was put on sin as the cause of leprosy and thus the proper remedy for it, sincere penance and reverence to the blood of Christ, combined

31 As was the case in Puritan New England, for instance, where the 1648 Laws and Liberties (following the 1641 Body of Liberties) excluded the possibility of religious pluralism and firmly forbade any religious tolerance granted to any other religion and Puritan congregationalism. In the words of Nathaniel Ward "all Familists, Antinomians, Anabaptists, and other Enthusiasts shall have free Liberty to keepe away from us, and such as will come to be gone as fast as they can, the sooner the better" (The Simple Cobbler of Aggawam 1647: 181). 
with "medical" treatments, such as the insistence on keeping bodily as well as spiritual cleanliness, was overlooked. For instance, the anonymous Naaman the Syrian, his disease and cure discovering lively to the reader the spiritual leprosie of sinne and self-love stated that "the Lord did teach his people by many bodily ceremonies, cleansing of leprosie by the Priest, and, washing by outward sacrifices, and the like. And by those many resemblances of the blood of the Paschall Lamb sprinkled, and the flesh of it eaten: ... he made the Lord Jesus and the power of his death and crosse to bee knowne" (D.R., 1642, page unnumbered). In early modern popular imagination and medicinal practice various uses of blood were still believed to be the most successful remedies for leprosy (Demaitre 2007: 268). The unavailability of pure blood explained the incurability of the illness, a view sustained by such works as Thomas Dekker's 1604 Nevves from Graves-ende, or the tale of Constantine, retold by the Puritan preacher Jeremiah Whitaker. The story of Constantine commented on human weaknesses and their consequences, on the body and on the soul, as many Protestants felt that the relationship between bodily and spiritual leprosy should be underscored more vividly. Many such discussions of leprosy thus made use of widely held medicinal beliefs about the properties and signs of leprosy. For instance, R. Mayhew's Love to the life, or, Some meditations upon loving, and washing in the blood of Christ (1674) states as follows:

\footnotetext{
Gehazi was no fuller of Leprosie then I am of Sin; and yet he went out of his Masters presence, a Leper as white as Snow.

A Sinner thou art, ... and no more thou art; now, though a Sinner be a Subject of misery, yet an object of Mercy. The Son of Man is come to seek, and to save, that which was lost.....

If I must go to Christ, to be washed in his Blood, then, what manner of Blood, is Christs Blood. Beloved!

... Christ can make a Feast of a Fragment. Take a Tast, though but a Tast. Christs Blood, is a Heartsoftning blood. The heart of Man is stony; yea, like an Adamant stone, concerning which stone, they say, that nothing but Goats-blood will soften it. Oh Soul, though thy heart be like an Adamant-stone; yea, like the nether Milstone, yet the blood of Christ can soften it. I will take away the stony heart out of their flesh, and will give them a heart of flesh.
}

(Love to the life, 91-92)

The conviction that the blood of lepers was grainy and sandy was widely held at least since the thirteenth century (Risse 1999: 171), and was frequently repeated in works such as the aforementioned De proprietatibus rerum or in early modern works such as John Betts' De ortu et natura sanguinis (1669): "[i]n Sanguine item Leprosi observatae sunt arenulae" (Betts 1669: 275). The conviction about the grainy nature of leprous blood combined with the image of Christ softening the stones of human hearts in Mayew's text thus works medical knowledge, 
including that goat liver or stomach could heal leprosy (De proprietatibus rerum) into a religious context and, relying on popular belief in both the redeeming powers of innocent or holy blood, and the stony properties of leprous blood, weaves a metaphor of leprosy as a spiritual disease healed by sacred blood, as physical leprosy could be cured by blood and faith.

\section{Objects and popular belief}

There were other, numerous uses of medical magic in both pre- and postReformation literature that were also tied to objects. For instance, the Arthurian tale of Sir Gareth and Dame Lynette, also in Malory's Morte D'Arthur, provides an interesting take on medicinal salves. Dame Lynette, trying to keep Sir Gareth from consummating his love to Dame Lyonesse before they are married, conjures up a knight that attacks Sir Gareth throughout the night. Each time they engage in combat Gareth beheads Lynette's knight, but each time she anoints his head with an ointment and he comes back to life, to fight Gareth again. The audience is assured of the knight's positive role in the tale because, as opposed to the Green Knight whose head is restored to the body without apparent help, and who later is proven to have been Morgan le Fay's agent, Lynette's knight is revived by her with the use of magic for the sake of virtue. Accordingly, she then cures Sir Gareth from the wounds he received in combat, and the story ends happily. Medicinal magic is therefore used for moral purposes. Many other tales, such as Eliduc (ca. 1180), Sir Isumbras (ca. 1320?), or Robert of Cicily (15 ${ }^{\text {th }}$ century) make similar use of objects that have both magical and medicinal properties. In Marie de France's Eliduc, for example, the near-dead Guilliadun is brought back to life through the use of a plant which Guildeleuc finds in a forest, having seen a weasel use the same flower to restore life to another weasel.

For Protestants popular belief connected to objects, including medicinal magic, became problematic, because while still popular, charmers and village healers were also part of the grey area of belief inherited from before the Reformation, and thus inconveniently Roman Catholic. For instance, the Puritan minister William Perkins complained that "[c]harming is in as great request as physic, and charmers more sought unto then physicians in time of need" (A Discourse of the Damned Art of Witchcraft, 1608: 153). ${ }^{32}$ Since most ministers recommended faith as a cure for everything, some uses of objects that were both medicinal and magical became obsolete, but many did not: people still went to "popular magicians" for medical aid which consisted of "a mixture of commonsensed remedies, based on accumulated experience of nursing and midwifery, combined with inherited lore about the healing properties of plants and minerals.

32 As quoted in Keith Thomas, Religion and the decline of magic (1973: 47). 
.... [I]t also included certain types of ritual healing, in which prayers, charms or spells accompanied the medicine" (Thomas 1973: 70). The religious qualities of medicinal magic allowed it to find a place in post-Reformation belief, perhaps to the annoyance of ministers, but clearly to the satisfaction of many who deemed this kind of 'alternative medicine' a normal part of life. As Keith Thomas points out, this sense of congruence of medicinal magic with life in post-Reformation England stemmed, to a large extent, from the perseverance of belief "in the curative power of the medieval Church" (Thomas 1973: 211) ${ }^{33}$ in that recourse to the saints, the Trinity, Virgin Mary, or Christ in prayers for healing (and so as part of the process of healing) created a link between religion, belief, and popular belief and established medicinal magic as part of the practice of belief in general. The sympathetic approach to magic and magical counselling of the Heads of the English Church, Elizabeth in 1555 and then James I with his 1597 Daemonologie, did not help ministers intent on purging 'superstition' either, ${ }^{34}$ but of course, superstition conveniently did not mean belief in demons, witches, or magic, but Roman Catholic belief in demons, witches, or magic.

All this indicates that "the various Protestant confessions did not succeed, in spite of their pious hopes and rhetoric, in expelling from the minds and lives of their adherents what their spokesmen were pleased to call "superstition" (Maxwell-Stuart 2002: 172). Multiple examples can be given to enumerate just a fraction of texts that propagated the medicinal value of magical practices, in which religious instruction and practice were mixed with popular belief. The use of objects featured prominently in such stories. For instance, broadside ballads, as well as works more religious in nature, such as Cotton Mather's Wonders of the Invisible World (1693) offered popular stories of the supernatural as means of moral instruction (about vice punished and virtue rewarded), in which objects featured prominently. In the 1685 Pack of Autolycus a story of George Sinclair illustrates how objects could also carry moral meaning. In the tale, George saw a ghost of a man that insisted George located a sword the man had given to someone before his death. Once George got it and followed the ghost to a certain spot, he asked: "“[w]hat would you have me to do [with] this thing?' The apparition responded that it wished: 'that the world may know that I murdered a man, and buried him in this place, in the year 1635'. Then the apparition laid down the sword, on the bare ground there, whereon grew nothing, but seemed to Goddard, to be as a grave sunk in; and then, the apparition, running further into the copse, vanished, and he saw it no more" (Pack of Autolycus, 173-174). The sword thus

33 Cf. Keith Thomas, Religion and the decline of magic (1973), especially chapter 7 throughout for more on this subject.

34 For more see Pierre Kapitaniak, "Reginald Scott and the circles of power: Witchcraft, antiCatholicism and faction politics", in Marcus Harmes \& Vitoria Bladen (eds.), Supernatural and secular power in Early Modern England (2016). 
has the magical, and moral, power of being a reminder of the ghost's crime and sin, and only confession and a public acknowledgment of guilt allowed the ghost to rest. While not medicinal, the sword is an object endowed with supernatural power, and features in a post-Reformation story (the kind of which was extremely popular throughout the seventeenth century) as evidence that in popular belief supernatural occurrences could be, and were, tied to objects.

For more ardent Protestants objects with supernatural properties or religious significance that could cure the spirit were also not unknown: gloves and rings given at funerals were customary ways of expressing grief and support, and distinguished mourners from other people in the community, ${ }^{35}$ for instance. Certain objects found place also in many Protestant religious practices: the cross carried important religious meaning for Anglicans, pocket Bibles were personal gateways to the divine, and pins and needles were objects associated with witchcraft. In the Tryal of Witches at the Assizes, held before Sir Mathew Hale (1683), for example, the evidence given against Rose Cullender and Amy Duny, accused in 1664 of bewitching seven people including two children, stated that the victims of Rose and Amy's witchcraft, among other symptoms, suffered pains in their stomachs as if they had swallowed needles. Samuel Pacy testified that the victims “.... would Cough extremely, and bring up much Flegme, and with the same crooked Pins, and one time a Two-penny Nail with a very broad head". The account further stated that these "Pins (amounting to Forty or more) together with the Two-penny Nail were produced in Court, with the affirmation of the said Deponent, that he was present when the said Nail was Vomited up, and also most of the Pins. Commonly at the end of every fit they [the victims] would cast up a Pin, and sometimes they would have four or five fits in one day" (Tryal of Witches, 1838 [1664], 9). As the sword of the Pack of Autolycus served to prove the guilt of the murderer, so the pins vomited by the victims of witchcraft served to prove the guilt of the witches, and led to their conviction and execution (item, 5).

There are a number of inferences to be drawn from this small set of examples. Firstly, it seems reasonable to observe that religion and religious belief were to a large extent the motivating force behind the uses of the supernatural in many of the mentioned texts. Secondly, the pattern of use of magical objects in pre- and post-Reformation England was irregular. Many objects such as ointments or herbs, rings, gloves, or swords, which served as tokens, charms, or cures, popular in the Middle Ages, retained a very mixed pattern of importance after the Reformation. Fear of idolatry and the Protestant policy of anti-Roman Catholic self-fashioning as anti-superstitious channelled the wide use of magical objects and their popularity in literary imagination into a much less frequent and much

35 See David Stannard, The Puritan way of death: A study in religion, culture, and social change (1977) and Peter Marshall, Beliefs and the dead in Reformation England (2002) for more on this subject. 
less vivid presence. However, in Puritan households in England and New England many magical objects, from lucky charms such as horseshoes, shoes buried under doorsteps or in walls, to cats buried in walls, were in wide use. ${ }^{36}$

Likewise, objects believed to belong to the realm of evil also frequented pages of moralizing stories and religious narratives: stones vomited by victims of witchcraft, or possessed houses, ladders, and drums of Increase Mather's Remarkable Providences (1684). In all instances, these objects were tied to words - vows to a ring, a prophecy or confession to a sword, relics to prayers, or blessings, etc. Words, in turn, were important both in popular belief and religion. The power of words tied to objects was a part of the English culture of belief, because religion was always practiced with the use of speech, not image or object alone. There is no "antithesis between spiritual (inward) and physical (outward) devotion" (van Bruaene 2016: 42) and this rings true in the coexistence of the supernatural nature of objects with the supernatural qualities of words. Words, then, and their relation to objects present another set of examples to consider the pattern of perseverance of aspects of popular belief in post-Reformation England.

\section{Words and popular belief: exorcism}

Words could be either written down in, for example, medical treatises, or spoken, for example during rituals, prayers, or exorcisms. Texts, of course, fulfilled a number of purposes. They could, for instance, serve as entertainment, as did Mathew Paris' 1294 narrative of a demon child in Herefordshire and its later replication in numerous, similar stories in Protestant England. ${ }^{37}$ Such texts could also serve a more godly purpose as published sermons or manuscript records of medical treatments, copied throughout the late Middle Ages and beyond (Saunders 2008: 180); numerous other texts served numerous other purposes. In a certain number of them, words featured prominently as channels of the supernatural. The shared area of the magic of words in both pre- and post-Reformation texts lies in the power of prayers, blessings, and curses. In Sir Gowther $\left(15^{\text {th }}\right.$ century) infertility, a medical problem, is addressed by Gowther's mother with a prayer, or rather, an incantation, to which a demon, an incubus, responds, putting Gowther's story in

36 See Ralph Merrifield, The archeology of ritual magic (1987). See also David Hall, Worlds of wonder, days of judgement: Popular religious belief in early New England (1990: 106-111).

37 These could also be used polemically, for instance derogatorily about Roman Catholics or heretics: Mary Dyer (Quaker) was said to have given birth to a deformed child due to her league with Satan, and Anne Hutchinson (Antinomian) apparently gave birth to thirty deformed fetuses at once. These monstrous births were narrated by John Winthrop, the governor of Massachusetts colony, who commented on these occurrences as follows: "see how the wisdom of God fitted this judgement to her sin in every way, for look as she had vented misshapen opinions, so she must bring forth deformed monsters" (Maxwell-Stuart 2002: 171). See also Julie Crawford, Marvelous Protestantism: Monstrous births in post-Reformation England (2005), especially chapter 4. 
motion. ${ }^{38}$ The tale contains a clear moral warning about resorting to magic and spells for achieving one's purposes, and asserts the power of the Church to mediate divine forgiveness. The whole story evolves round the power of words: of Gowther's mother, of the Pope who assigned Gowther his penance and forbade him to speak, of the silent Gowther and the muteness of the Emperor's daughter whose miraculous vocalization is a sign of Gowther's redemption, and so on. In Mirk's The Festial ghosts visit the living to tell them of the pains of purgatory, and demonic voices call out to the people they haunt in Mather's Remarkable Providences (1684). Clerical confession manuals such as Mirk's Instructions for Parish Priests (c. 1400-1450), and works such as Anthony Gilby's A Pleasant Dialogue (1581), William Est's The Right Rule of a Religious Life (1616), Edmund Calamy's England's Looking-Glasse (1642) or Thomas Laurence's Two Sermons (1635) gave testimony to the powerful nature of the Holy Word, the words of the priests, forms of rituals, and the immediate relation of the words spoken by the priest to God, in confession as much as during sermons, in what Mary Hayes calls "divine ventriloquism", ${ }^{39}$ a priest being a channel for God's word. Thomas Laurence lamented that in his time much less reverence was given to the voice of the clergyman than it used to be, so as everyone seemed to deem themselves worthy of preaching and talking about theology, and so he wished that "all would not preach which can speak; because St Paul calls every family a church, would not turn every table's end into a pulpit; that the feet in this body should not presume to see nor the hands to speak" ${ }^{40}$ While indeed under increased criticism, the power of words of the clergy both before and after the Reformation was considerable. It is in the role of the clergy, their words, and the voice of God that these are to utter where we come to one of the most vivid and evocative examples of the power of words in popular belief: exorcism. ${ }^{41}$

Exorcising demons, a practice applied throughout antiquity and early Christianity, acquired a new form and rules of practice in the fourteenth and fifteenth century. Through papal decrees, exorcism became a formal rite with a script that was comprised of "didactic texts that aim to authorize and regularize a particular set of ideas about spirit possession, sin, demonic activity, and ecclesiastical authority" (Caciola 2003: 227), rather than being an informal set of

38 See studies on this text in Albrecht Classen (ed.), Violence in medieval courtly literature: A casebook (2004).

39 Mary Hayes, Divine ventriloquism in medieval English literature (2011).

40 All four quotations adapted from David Zaret, The heavenly contract: Ideology and organization in pre-revolutionary Puritanism (1985: 93-94).

41 I will use the terms 'exorcism' and 'dispossession' interchangeably in the section on Protestants, but they are in fact two distinct words, exorcism referring to the Roman Catholic (or preReformation) practice of expelling demons, whereas dispossession being the term Protestants preferred to use to refer to their practices of expelling demons. 
words and gestures, and uses of various objects and spaces, to be used and interpreted fairly freely. While earlier versions of exorcisms relied on the divine influence of saints and angels, the fifteenth century saw more focus being placed on the words of the exorcist himself, and a significant increase in the production of exorcism booklets and portable manuals which enhanced the power of words conveyed in the rite of exorcism, because they were now not only uttered during the spectacle but also written down. Even though the rite was completely formalized officially, there were in fact multiple 'scripts' for exorcisms, and the printed exorcism booklets often contained multiple versions of a rite; there is evidence that they were used both by clergymen and laymen (Caciola 2003: 236241). Increasingly, though, priests came to comprise the majority of exorcists, and the prominence of men of God as those who successfully, and thus preferably, were tasked with banishing demons was underscored in many late medieval works.

Tales of the Devil possessing the soul of a sinner and then dragging it to hell highlighted fear of demons that preyed on sinful souls. For instance, the fourteenth-century Handlyng Synne (c. 1303) narrates the following story:

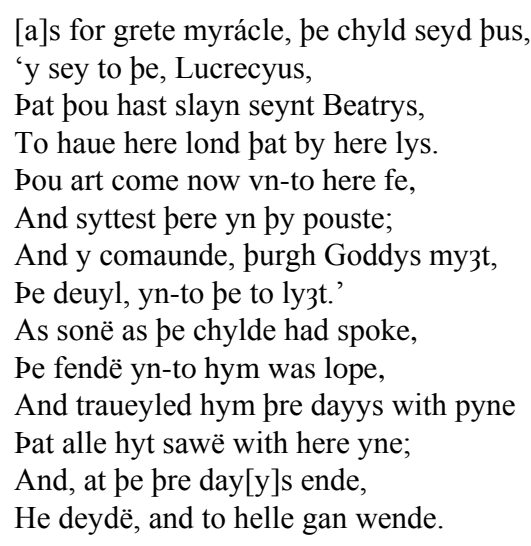

(Handlyng synne, 11. 6025-6038, p. 195) ${ }^{42}$

Lucretius, just like many sinners in Jacob's Well (c. 1440), or Mirk's Festial (c. 1380-1400), is punished for his sin by being tortured by devils after his death. The Devil also possesses him before his death, and torments him in order for Lucretius to die in agony. Devils assailing a soul before its death were a popular pre-Reformation motif. The late medieval ars moriendi works, for instance, popularized the image of devils seated by the dying person's bedside, trying to tempt them into sin so that they cannot be shriven, or by the bedsides of blatant

42 Robert Mannyng, fl. 1288-1338, William de Wadington, $13^{\text {th }}$ cent., in Furnivall, Frederick James, 1825-1910, University of Michigan online edition.

http://quod.lib.umich.edu/cgi/t/text/textidx?c=cme;cc=cme;view=toc;idno=AHA2735.0001.001 
sinners, sniggering at the prospect of snaring and dragging them to hell. Belief in devils eager to possess sinners was also augmented by theological assent: demonic possession was a theologically accepted truth and a real medical possibility ${ }^{43}$. There were different kinds of demons discussed by various theologians, for instance Aquinas in his Summa Theologiae (c. 1274): incubi, succubi, material and immaterial, in human form (most often female, or of a man wearing black), or in animal or hybrid form, but regardless of their guise they were always at the edge of sight, waiting for the proper moment to strike.

Possession itself was both a supernatural state in which the body and soul were assailed by a supernatural force and a physical state in which the body and mind were under distress (Watkins 2007: 55-60). The priest or cleric who defeated the demon through the voice and power of God was the bridge between preReformation concepts of magic which involved demons, science, as demonic possession was considered one of the reasons for mental illness (KatajalaPeltomaa 2014: 108-127), and religion which acknowledged the existence of demons and God's power as cure. England, however, had a certain problem with this model: the papal bulls and laws on exorcisms in England were only partially implemented in practice and so "[1]iturgical exorcisms largely failed to make an impact in medieval England ... . The rising fear of magic and sorcery in fourteenth-century Europe had comparatively little effect in England, and the idea of demonic possession never seems to have taken hold" (Young 2016: 96), although of course this is only partially true. Nevertheless, notwithstanding the abundance of stories about demons and devils, very few exorcisms were actually performed in pre-Reformation England, because as much as belief in demons was widespread, demonic possession, it seems, was much less so.

Less formal ways of exorcising demons (including holy water) seem to have been much more popular in pre-Reformation England. And for that reason sixteenth-century Reformers "attacked exorcism of objects instead" (Young 2016: 95). Milner (2011: 143) disagrees that only baptism and object exorcisms were performed in pre-Reformation England and that exorcism was completely insignificant, suggesting instead that their textual records were simply lost, and draws attention not to their form, which was not fixed as they were not a sacrament, but to their ritualistic properties. Exorcism as a ritual involved prayers, certain gestures, and words to be said in specific circumstances, by certain people. It narrated its supernatural defence to its supernatural enemy with words that evoked the power of God through the voice of the priest, and banished the demon

43 For more on this subject, see Catherine Rider, "Demons and mental disorder in late medieval medicine", in Sari Katajala-Peltomaa \& Susanna Niiranen (eds.), Mental (dis)order in later medieval Europe (2014). See also Albrecht Classen (ed.), Mental health, spirituality, and religion (2015). 
or devil through words of faith, but also by eliciting confession, contrition for sin, or by giving rise to moral thoughts. The first defence against demonic possession was the power of holy words: the priest (or exorcist) or the afflicted himself or herself addressed the demon using proper, often pre-determined words that were to banish the assailant (or make it reveal secrets) (Adams 2007: 105), as an interrogation of a witch was to reveal their connection to the Devil and the secrets of their magic. If prayer failed physical contact was established through holy water, or the rosary, or the cross, that were to work in conjunction with words, making exorcism both verbal and physical (Milner 2011: 143), in combination an effective way of getting rid of the demon. All those actions, in turn, were usually tied to a text, an exorcism manual of one kind or another (perhaps with the addition of custom-related practices), and the Bible: a book that was an object, and yet carried powerful words. Words in an exorcism were an anti-spell against the power that assailed the possessed. Both the concept of demonic possession and its cure were strongly connected to witchcraft and evil spells, as one conjured demons through magic, or bewitched someone into being possessed through an illicit relationship with the Devil (Adams 2007: 101-103). ${ }^{44}$ In that duality of meaning, possession as enacted by demons, but caused by witchcraft became the most widespread interpretation of demonic possession in pre-Reformation England, the force of the Devil acting both through the witch who summoned the evil spirit, and the demon that haunted the living. Such demonologies, or witchcraft theories, as the 1462 Flagellum Maleficorum were "employed as aids in the identification and prosecution of witches" (Williams 2013: 69), ${ }^{45}$ and aided both the exorcists and inquisitors (witchcraft was prosecuted as heresy) in identifying the witch responsible, as "the demon confirmed the charge by naming the witch that had conjured him or sometimes by convulsing in the witch's presence" (Wenegrat 2001: 82). This conflation of demonic possession with witchcraft formed the foundation for the post-Reformation understanding of the role of exorcism, and its Protestant uses.

Witchcraft in Early Modern England was not only an accepted fact; it was scorned as the pact made with the Devil by witches was seen as an inversion of the covenant with God. Witchcraft was also a subject of confessional polemic, and occasionally of scepticism. Since the fifteenth century, England produced writers who claimed that witchcraft and demonic possessions were either illusions sent by Satan, or were simply made up by human error and mischievousness. This

44 See also Brian Levack's The witch-hunt in Early Modern Europe (2006): "[t]he emergence of the belief that witches were not merely magicians but also devil-worshippers changed the nature of the crime of witchcraft. It made witches not simply felons, similar to murderers and thieves, but heretics and apostates, intrinsically evil individuals who had rejected their Christian faith and had decided instead to serve God's enemy, the Devil" (Levack 2006: 8).

45 Cf. also Williams (2013: 69-83). 
scepticism was reflected in the irregular pattern of exorcisms in fifteenth- and sixteenth-century England (Williams 2013: 73-74), as for the number of reported cases of demonic possession there was not a matching number of exorcisms performed. However, while sceptical voices did not cease to speak against belief in witchcraft, and works such as Reginald Scot's Discoverie of Witchcraft (1584) voiced concerns about the truthfulness of many bewitching and possessions, the majority of both divines and laity in post-Reformation England did believe in witchcraft and the reality of demonic possession. Especially after 1570 there was a noticeable increase in Protestant treatises on witchcraft and various demonologies because the connection between witches and the Devil, their unchristian ethos, and anti-Christian goals came to the foreground of pastoral and devotional concerns. The Devil was close, "personal", and his force immense and frightening to postReformation audiences as much as to their ancestors: "the Reformation did nothing to weaken this concept; indeed, it almost certainly straightened it. ... Influential preachers filled the ears of their hearers with tales of diabolic intervention in daily life, recognizable as the cautionary exempla of the Middle Ages brought up to date" (Thomas 1973: 189). Indeed, theological truths about the existence of devils, demons, and their connection to witches, by thinkers from both the Middle Ages and the early modern period, such as Thomas Aquinas (1225-1274), Hugh Latimer (1487-1555), or William Perkins (1558-1602) ${ }^{46}$ were commonly acknowledged. Demonology in post-Reformation England, then, in many ways was seen as synonymous to witchcraft, and functioned in popular early modern imagination regardless of whether someone believed in demonic possession at face value, or considered it a trick of the papists. The Devil after the Reformation could possess souls for as long as thirty years before the possessed died, in contrast to the majority of pre-Reformation texts that talked about possession happening closely before death, at least according to some ministers who told certain members of their churches that the Devil was sitting on their shoulders, or that He would possess them if they take the Lord's Supper being evil at heart (Thomas 1973: 189).

Demonic possession in Post-Reformation England, then, could mean two things: a true ailment someone was suffering, or a lie. If someone was found to be truly possessed, it proved the existence and dangers of witchcraft, and could be used to ascertain the theological purity of a given confession and be used polemically, on top of being an important confirmation of popular belief. If it turned out to be a lie, it was a trick used to beguile naive laity by an opposing confessional faction, or was proof of the falseness of the Devil ${ }^{47}$ who incited the counterfeit demoniac to lie about their possession to ridicule the attempts of the

46 William Perkins, Discourse of the Damned Art of Witchcraft (1608).

47 See also Walter Hilton's Scale of Perfection (c. 1382) for a discussion of how the Devil sent visions that were to fool the faithful into believing they were seeing angels. 
ministers to banish the demon. The inter-confessional polemic of demonic possession, and even more so, dispossessions, was inseparably tied to popular belief and faith. In post-Reformation England religious policy and propaganda went hand in hand with belief and magic in the interpretation, and performance, of exorcisms. Protestants were well acquainted with the concept of exorcism, and knew the Roman Catholic rite very well. Exorcism was a powerful tool of proving the 'correctness' of a given confession (be it Protestant or Roman Catholic) and a confirmation of the God-given power of the clergyman, "both confessions... sought to display its superior efficacy (and therefore its superior hold on theological truth), in the use of exorcism to expel the offending spirit" (MaxwellStuart 2002: 172). As a tool of confessional rhetoric, narratives of exorcism were thus a weapon, and all confessions could find themselves under attack. Depending on the origin of a narrative, a demon just before being cast out revealed which religion he applauded and which scared him: in Roman Catholic narratives the devil loved Protestantism but was afraid of Catholicism, whereas in Puritan exorcism narratives the devil supported Roman Catholicism as well as Anglicanism, but was terrified of Calvin and Puritan prayers. A particularly intense conflict in this matter ensued between Anglicanism and Puritanism. The Church of England participated the least in this exorcist polemical war and was thus anxious to discredit Puritanism and its expertise in such rhetoric, because as opposed to Roman Catholicism, Puritanism was becoming (towards the end of the sixteenth century) a dissenting political and religious force in England to be reckoned with (Wenegrat 2001: 82).

One such famous attempt to debunk Puritan dispossessions by the Church of England was its feud between Richard Bancroft, bishop of London, supported by Samuel Harsnett, Archbishop of York, and John Darrell and his supporters (Freeman 2000: 34-35). A Protestant clergyman, Darell had strong Puritan convictions and by the 1580 s became a renowned exorcist. His renown was also his undoing. As it turned out, his exorcisms in 1597, most notably of William Somers, were later ruled to be fraud, because William admitted he lied about being possessed and claimed that he had simulated his fits. A few other former demoniacs exorcised by Darrell also admitted they were pretending to be possessed, and in 1597 Darrell was put on trial for fraud. He was convicted and stripped of his preaching license in 1599, but his punishment caused outrage on the side of many Puritans, who embarked on a lengthy 'print battle' with Bancroft and Harsnett, writing in defence of Darrell and condemning the Anglican restrictions on dispossessions. On the side of the established Church, the key issue was ecclesiastical dominance, and less the practice of expelling demons itself: the widespread, through Darrell's activity, confirmation of the efficacy of Puritan exorcism posed a threat to the ecclesiastical power of the Anglican Church, and positioned Puritans on the same side as Roman Catholics, as enemies of the 
Church of England (van Dijkhuizen 2007: 93). Bancroft did not care if demons were being expelled by prayer and fasting (though that was the only acceptable way). What he did care about was that this simple Protestant manner of fighting demons was used in ways that he neither approved of, nor that were good for the Church of England and its reputation. On top of that there was the problem of the ritualization of exorcism: the Anglicans did not approve of how the Puritans (Darrell in particular) turned dispossessions into elaborate public spectacles, while Darrell and many other Puritans claimed that they never went beyond the direction of prayer and fasting only. In other words, the Anglicans found themselves without a competitive form of dispossessions, whereas both Roman Catholics and Puritans had attractive, and apparently successful, semi-rituals that drew large crowds, including many Anglican laity, to each performance. The Puritans could also aid Anglicans should they fall victim of possession.

It was thus Puritan exorcism that became the hallmark of post-Reformation belief in demonic possession, and was a mix of Puritanism and a selection of preReformation aspects of exorcism. Protestant ministers in general, including Anglicans, in accordance with one of the basic tenets of Protestantism, could no longer command demons to leave a possessed body. They could, however, apply prayer and fasting "that entreated God to cast [the demon] out" (Johnstone 2006: 389-390). Puritans, particularly John Darrell, but also John Foxe, Robert Balsom, or Richard Rothwell, took this to another level, and reshaped this fairly vague guideline into a spectacular framework, nothing short of a ritual which would have certain stages, and come to the inevitable conclusion of banishing the demon in the name of God (because He supported Puritanism). In all instances of Protestant exorcism, the power of words was central to its efficacy, as well as to any added value of contributing to its self-promoting polemic. A physical engagement with the possessed was also not unheard of. For instance, John Lane, exorcising Anne Mylner in 1564, held her down, poured vinegar down her nostrils, and then asked the onlookers and participants to recite Te Deum (Sands 2000: 446). Cotton Mather was accused by Robert Calef in 1692 of indecent conduct with a teenage female demoniac, whose breasts and stomach he stroked during the dispossession, though Mather asserted that this was a part of the ritual and was to calm her down (Delbanco 1989: 233). There was one physical aspect of Puritan exorcism that featured in most performances in particular: the use of the Bible. It was "employed as a magical object, to be used in testing for witchcraft or as protective amulet against the unwelcome activities of preternatural beings" (Maxwell-Stuart 2002: 173) because it was understood to be a powerful relic metaphorically (Ryrie 2013: 294) as much as literally by superstitious laity. It was equally reverently used in exorcist practices by ministers and audiences. Bibles for Protestants were personalized objects of worship, much like the pre-Reformation books of hours but more intensely intimate. Turning the pages of the Bible was almost as sensual as 
touching the beads of a rosary in prayer. During exorcisms various citations from the Bible were used in exorcist prayers, either as quotations or, more often, as foundations for lengthy prayers and short sermons said over the demoniac, and each Protestant exorcist carried his pocket Bible with him. In this as well the Puritan exorcism resembled Roman Catholic exorcism, as it too had prayers and formulas incanted before the possessed, except Puritan ministers did not hold to prescribed words, gestures, and formulas in the process, although they could, and sometimes did, ${ }^{48}$ but chose instead to rely on the Scripture.

Puritan exorcisms in many ways resembled pre-Reformation exorcisms more than Roman Catholic rites contemporary to them, which were more formalized than they were in the fifteenth century. The pre-Reformation model was that of fluidity and relative freedom of conduct, focusing on the healing of the possessed soul, and could be performed in any place, by anyone (clergyman or layman), and with the use of both words and objects, as appropriate, with the participation of the exorcist, but also of the possessed (who could also try to reason with the demon) and the gathered audience. The 1602 exorcism of Mary Glover, conducted by six Puritan ministers (Barber, Evans, Lewes, Skelton, Bridger, Swan), ${ }^{49}$ had precisely such a form. The 1603 account by John Swan, A Treve and breife report, of Mary Glovers vexation is a detailed narrative intended to support the cause of Puritan exorcism, and thus underscores the power of prayer and fasting, though in fact it focuses on the power of prayer, and of words only. In the lengthy description of the fits Mary experienced, and in the detailed citation of the prayers and sermons that were said over her bed, we get a good idea of what a Puritan exorcism looked like. And it looked as follows: fasting preceded the day of the dispossession, then the ministers took turns in saying prayers and sermons over the demoniac, and the gathered audience supplemented these prayers with responses much alike a service or rite. In the meantime, Mary was experiencing various kinds of fits and other bodily sensations, from wringing her hands, pain in her stomach, shut eyelids, blackened tongue, to more violent vexations that increased as the prayers increased in intensity and their implorations to God. At the peak of the exorcism, Mary was raised off the bed with unusual force and stood on her toes only, overcame men who wanted to restrain her, and then vomited a strange kind of foam into the face of one of the exorcists.

The role of voice is clearly visible in this narrative. Earlier Mary said prayers in a weak voice, to aid the ministers in their task, but as the fits increased and the prayers continued her voice became "very strange, proceeding from the throat (like a hoarce dogge that barkes) casting from thence with open mouth aboundance of froath or foame ... . The noyse and sound of her voice one expresseth (in his noates of observation) by the word cheh cheh, or keck keck:

48 For example as in the use of Latin prayers (Thomas 1973: 210).

49 Who were also briefly imprisoned for this, for the same reasons as John Darrell. 
another of a violent twishe twishe, or the hissinge of a violent Squibbe" (A Treve and brief report, 1603: 42). Her voice, while it could participate in the exorcism through prayers, was inhuman and horrid at the height of the demon's struggle with the ministers, and was mute apart from the sounds that were coming from her throat. The dispossession was ultimately successful and so afterwards, when the demon left her body, Mary recovered her senses and could again speak, delivering a thanksgiving speech and prayer. ${ }^{50}$ The reason why the dispossession was successful was, because the ministers who conducted it were "continually either the mouth of God to vs, in deliueringe sweet aud apt meditations ... or els the mouth of vs, to send up our prayers \& supplications" (A Treve and brief report, 1603: 2). The clergymen were, then, the ventriloquists of God, and spoke with His voice, or delivered the voice of the faithful to Him; they were channels of divine speech, and it was the power of their words that healed the possessed. For Protestants the power of words stemmed from Christ, but not unlike preReformation exorcisms in which it was likewise advised that exorcisms were best done by qualified clergymen, armed with the power of God's Word, also in this case it was ministers who were the preferred exorcists ${ }^{51}$. Even though the words spoken by ministers were not considered to have a directly occult meaning, the popularity of certain exorcists, like John Darrell, over others suggests that to some extent certain individuals were considered more gifted in the art of anti-demonic prayer then others (Freeman 2000: 37).

\section{Conclusion}

The examples recounted here are, of course, limited in number, and cannot even begin to shed light on the full form and complexity of post-Reformation popular belief. But there are certain conclusions that can be drawn from the discussed material. The religion-driven reasoning and religious importance of belief in certain things mediated belief in other things, the more connected to religion the better. In cases where they were not (like ghost stories), such beliefs were appropriated by religious discourse, imagery, and practices, in attempts to tackle their 'othering' qualities, but which in effect perpetuated their appeal and sanctioned their presence in popular imagination. Religion and popular belief reinforced each other in acknowledging the existence of supernatural entities that lurked in the shadows to do harm, and as religion offered cures for certain kinds of devotional fears through confession, communal religious practices, individual

For more on the expulsion of demons see Levack (2013: 81-112).

And this came with further restrictions in the Church of England, as a minister could only perform an exorcism after obtaining permission from their bishop, though many Puritan clergymen did not adhere to that rule (Freeman 2000: 35-36). 
piety, or religious imagery, so popular belief offered cures for other fears resulting from post-Reformation confessional tensions and uncertainty about aspects of devotion, belief, and religious culture that could not be cured by religion itself. The success with which popular belief resisted anti-superstition rhetoric and doctrinal changes in religion is due to its usefulness. In confessional politics it was a convenient form of derogatory differentiation or a way of grabbing the interest of the laity to persuade them to subscribe to a given confession's take on practices like exorcism. It also offered motifs to be evocatively used for moralizing purposes in sermons and other texts. Thus ghost stories served clergymen in narratives of God's vengeance on sinners, and belief in demons and devils opened up possibilities of arguing for superior theological tenets of factions that could claim successful exorcisms and dispossessions. Many of these aspects of popular belief originated before the Reformation and were allowed to survive by clergymen and theologians as useful, while surviving also among the laity as traditional, familiar, deeply English and thus a safe cultural space untouched by the turmoil of the times.

Popular belief thus served two purposes related to the communities in which it functioned. Medicinal magic reflected beliefs that were as deeply saturated with religious belief, such as that blood cures leprosy as Christ's blood cures sin, as they were with the practicalities of life in which some illnesses could not be cured otherwise than through belief. And as these uses of medicinal magic motifs grew more intense, post-Reformation writers put them into use as rhetorical tools of moral commentary while acknowledging that the practices this commentary referred to were actual practices of their audiences. The physical experiences narrated through tales of medicinal magic related to the spiritual and cultural experiences of their writers and readers, always serving its double purpose: of comfort induced by familiarity and immutability, and as a useful tool of persuasion of the supremacy of certain religious tenets, such as the efficacy of baptism or the power of the Bible. Objects and words that belonged to both medicinal and non-medicinal practices fulfilled the same two purposes, most persuasively applied in the practice of Protestant dispossessions. As public spectacles, dispossessions served two purposes. To the ministers enacting the spectacles of dispossession served to further their pastoral agendas and devotional and theological policies, reinforcing confessional uses of objects such as the cross or Bible, by opening space for an entertaining performance that worked like an elaborate sermon. To the popular audience dispossessions served as proof that there was a cure for evil that could not be otherwise cured: demonic possession, and witchcraft. Religion shaped these responses to exorcisms as much as it shaped their often contested form, making dispossessions a good example of the self-sufficiency of the English culture of belief after the Reformation: it created a problem, demonic possession, through a conflation of theology and popular 
belief, and then produced a cure that constituted of theological truth seasoned with belief in the power of certain objects, words, people, and practices.

In other words, the lack of conflict between pre- and post-Reformation popular belief, its recurring usefulness to religious agendas and confessional policies, and its imperviousness to a politically selective discourse of superstition helped to create a culture of belief in post-Reformation England that was simultaneously religious and popular, selective and inclusive, theoretical and practical, traditional and changed. Texts like Increase Mather's Remarkable Providences (1684) reflect a mind-set in which belief in the supernatural was not denied, but simply turned around to support the confessional agenda of the Protestants, building on the widely held belief that houses, people, or objects could be bewitched, and that there were certain prescribed and safe ways to counter such malevolent magic. Mather, as a minister, knew that stories such as the one he narrated would be understood for what they were: a warning against witchcraft and a recipe for how to fight it, but he also knew that the only way to make his message sink in with his audience was to deliver a convincing narrative of the possession of Mr. Mompesson's house that relied on popular concepts of demonic possession, because the more his readers were thrilled by the scariness of the story, the more supportive they would be of punishing witches. Mather and many other authors of his time knew that religion was the principle of life in England, and that popular belief was an inseparable part of both.

\section{REFERENCES}

\section{PRIMARY SOURCES}

Anglicus, Bartholomeus. 1582 [1538]. Batman vppon Bartholome his booke De proprietatibus rerum, 2nd edn. EEBO, STC.

Anonymous. 2007. Amys and Amiloun [1330-1400]. In Edward E. Foster (ed.), Amis and Amiloun, Robert of Cisyle, and Sir Amadace. Kalamazoo: Medieval Institute Publications, online edition, http://d.lib.rochester.edu/teams/text/foster-amis-and-amiloun.

Anonymous. 2012 [1430]. Prick of Conscience. In James H. Morey (ed.), Prick of Conscience, Kalamazoo: Medieval Institute Publications.

Anonymous. 1679. A Discourse of the Repugnancy of Sin to the Principles of Universal Reason Being a Dissuasive From a Sinful Life From Principles of Common Wisdom Currant Amongst All Mankind, Save Onely in the Concerns of Their Souls, London: Printed and are to be sold by Edward Millington ... and William Abington ... . EEBO, Wing/D1608 Variant.

Anonymous. 1905. Jacob's Well [1440]. Early English Text Society Publication. London: Kegan Paul.

Anonymous. 2014 [1992]. Jaufré [c. 1220?]. In Ross G. Arthur (ed.), Jaufre: An Occitan Arthurian romance. New York: Routledge. 
Anonymous. 1642. Naaman the Syrian, his disease and cure discovering lively to the reader the spiritual leprosie of sinne and self-love. D.R. 1642, EEBO, Wing/ R1799.

Anonymous. 1995. Sir Gowther [c.1380]. In Anne Laskaya and Eve Salisbury (eds.), The Middle English Breton lays. Kalamazoo: Medieval Institute Publications.

Anonymous. 1605. The history of the tryall of cheualry vith the life and death of Caualiero Dicke Bowyer. As it hath bin lately acted by the right Honourable the Earle of Darby his seruants, 2nd edn. EEBO, STC/13527.

Anonymous. 2006. Sir Isumbras [c. 1320?]. In Harriet Hudson (ed.), Four Middle English romances: Sir Isumbras, Octavian, Sir Eglamour or Artois, Sir Tryamour. Kalamazoo: Medieval Institute Publications, online edition. http://d.lib.rochester.edu/teams/text/hudson-sir-isumbras

Anonymous. 2007. Robert of Cicily [15 ${ }^{\text {th }}$ century]. In Edward E. Foster (ed.), Amis and Amiloun, Robert of Cisyle, and Sir Amadace. Kalamazoo: Medieval Institute Publications, online edition, http://d.lib.rochester.edu/teams/text/foster-robert-of-cisyle.

Aquinas, Thomas. 1947 [1274]. Summa Theologica. (Translated by Fathers of the English Dominican Province.) Cincinnati: Benziger Brothers.

Betts, John. 1669. De Ortu et Natura Sanguinis a Joanne Betto. EEBO, Wing/ B2087.

Bolton, Robert. 1640. A Cordiall for Christians in the Time of Affliction. Or, A sermon Preached at Kethering Lecture by Master Robert Bolton, Bachelour of Divinity, and sometimes fellow of Brasen-nose Colledge in Oxford. Published by I.S., 2nd edn. EEBO, STC/3227.

Calamy, Edmund. 1642. Englands Looking-Glasse Presented in a Sermon, Preached before the Honorable House of Commons at their Late Solemn Fast, December 22, 1641/ by Edmund Calamy, B.D. and preacher at Aldermanbury, London, 2nd edn. EEBO, Wing/C236.

Caluin, Iohn. 1561 [1559]. The Institvtion of Christian Religion, vvrytten in Latine by Maister Ihon Caluin, and Translated into Englysh According to the Authors Last Edition. Translated by Thomas Norton, 2nd edn. EEBO, STC/4415.

Davies, John. 1605. Microcosmos The Discovery of the Little World, with the Governement Thereof. By Iohn Davies, 2nd edn. EEBO, STC/6334.

De France, Marie. 1999. Eliduc [c. 1180]. The lais of Marie De France: With two further lais in the original Old French, 111-126. (Translated by Glyn Burgess. Introduction by Keith Busby.) London: Penguin.

Dekker, Thomas. 1604. Nevves from Graues-end Sent to Nobody, 2nd edn. EEBO STC/12199.

Edwards, Thomas. 1646. The First and Second Part of Gangraena, or, A Catalogue and Discovery of Many of the Errors, Heresies, Blasphemies and Pernicious Practices of the Sectaries of This Time, Vented and Acted in England in These Four Last Years also a Particular Narration of Divers Stories, Remarkable Passages, Letters: an Extract of Many Letters, all Concerning the Present Sects: Together with Some Observations Upon and Corollaries from All the Fore-named Premises. EEBO, Wing/E227.

Est, William. 1616. The Right Rule of a Religious Life: or, The glasse of godlinesse Wherein euery man may behold his imperfections, how farre hee is out of the way of true Godlinesse, and learne to reduce his wandring steppes into the pathes of true pietie. In certaine lectures vpon the first chapter of the Epistle of S. Iames. The first part. By William Est preacher of Gods Word, 2nd edn. EEBO, STC/10536. 
Gilby, Anthony. 1581. A Pleasant Dialogue, betweene a souldior of Barwicke, and an English chaplaine Wherein are largely handled \& laide open, such reasons as are brought in for maintenaunce of popishe traditions in our Eng. church. Also is collected, as in a short table, 120. particular corruptions yet remaining in our saide church, with sundrie other matters, necessary to be knowen of all persons. Togither with a letter of the same author, placed before this booke, in vvay of a preface. EEBO, STC/11888.

Gower, John. 2006. Confessio Amantis [c. 1390]. In Russel A. Peck (ed.), Confessio Amantis, Volume 1. (Translated by Andrew Galloway.) Kalamazoo: Medieval Institute Publications (Middle English Text Series).

Hale, Matthew. 1683. A Tryal of witches, at the assizes held at Bury St. Edmonds, for the county of Suffolk, on the 10th of March 1664, before the said Sir Matthew Hale. EEBO, Wing/H260.

Hilton, Walter. 2000. Scale of Perfection [c. 1382]. In Thomas H. Bestul (ed.), The Scale of Perfection. Kalamazoo: Medieval Institute Publications.

Langland, William. 1967. Piers Plowman [c. 1370-1390]. In Elizabeth Salter \& Derek Pearsall (eds.), Piers Plowman (C-text). Evanston: Northwestern University Press.

Laurence, Thomas. 1635. Two Sermons, The First Preached at St Maries in Oxford Iuly 13. 1634. Being Act-Sunday. The Second, in the Cathedrall Church of Sarum, at the Visitation of the most Reverend Father in God William Arch-Bishop of Canterbury, May 23. 1634. By Thomas Laurence Dr of Divinity, and late Fellow of Allsoules Colledge, and Chaplaine to his Maiesty in Ordinary, 2nd edn. EEBO, STC/15328.

Malory, Thomas. 2008. Le Morte D'Arthur [1485]. In Helen Cooper (ed.), Le Morte D'Arthur. The Winchester Manuscript. Oxford: Oxford University Press.

Mannyng, Robert. 1303. Handlyng Synne [fl. 1288-1338]. In Frederick James Furnivall (ed.), Handlyng Synne. London: Kegan Paul. (University of Michigan online edition.) http://quod.lib.umich.edu/cgi/t/text/textidx?c=cme;cc=cme;view=toc;idno=AHA2735 .0001 .001

Mather, Cotton. 1693. The Wonders of the Invisible World being an Account of the Tryals of Several VVitches lately Excuted [sic] in New-England, and of Several Remarkable Curiosities therein Occurring: together with, I. Observations Upon the Nature, the Number, and the Operations of the Devils, II. A Short Narrative of a Late Outrage Committed by a Knot of Witches in Swede-land, very much Resembling and so far Explaining that Under which New-England has Laboured, III. Some Councels Directing a Due Improvement of the Terrible Things Lately Done by the Unusual and Amazing Range of Evil-Spirits in New-England, IV. A Brief Discourse Upon those Temptations Which Are the More Ordinary Devices of Satan/ by Cotton Mather. EEBO, Wing/M1175.

Mather, Increase. 1684. Remarkable Providences: An Essay for the Recording of Illustrious Providences Wherein an Account is Given of Many Remarkable and Very Memorable Events, which have Hapned this Last Age, Especially in New-Englands, 2nd edn. EEBO, Wing/M1208.

Mayhew, R. 1674. Love to the Life, or, Some Meditations Upon Loving, and Washing in the Blood of Christ Together, with a Tast of Gospel-Promises, as the Churches Stock, or, Believers Patrimony, 2nd edn. EEBO, Wing/M1440.

Mirk, John. 1905. The Festial [c. 1380-1400]. In Theodore Erbe (ed.), The Festial. (Early English Text Society.) London: Kegan Paul. 
Mirk, John. 1902. Instructions for Parish Priests. In Edward Peacock (ed.), Instructions for Parish Priests. (Early English Text Society.) London: Kegan Paul.

Narne, William. 1630 The Pearle of Prayer Most Pretious and Powerfull, or, A Christian Treatise Most Necessarie for all These That Desire to Shew that Wrath to Come ... By Mr. William Narne, 2nd edn. EEBO, STC/18360.

Perkins, William. 1608. A Discourse of the Damned Art of Witchcraft so Farre Forth as it is Reuealed in the Scriptures, and Manifest by True Experience. Framed and Deliuered by M. William Perkins, in His Ordinarie Course of Preaching, and Now Published by Tho. Pickering Batchelour of Diuinitie, and Minister of Finchingfield in Essex. Whereunto is Adioyned a Twofold Table; One of the Order and Heades of the Treatise; Another of the Texts of Scripture Explaned, or Vindicated from the Corrupt Interpretation of the Aduersarie, 2nd edn. EEBO, STC/19697.

Rollins, Hyder Edward. 2013. The Pack of Autolycus: Or, Strange and Terrible News of Ghosts, Apparitions, Monstrous Births, Showers of Wheat, Judgments of God, and Other Prodigious and Fearful Happenings as Told in Broadside Ballads of the Years 16241693. Cambridge: Harvard University Press.

Scot, Reginald. 1584. The Discouerie of Witchcraft VVherein the Lewde Dealing of Witches and Witchmongers is Notablie Detected, the Knauerie of Coniurors, the Impietie of Inchantors, the Follie of Soothsaiers, the Impudent Falshood of Cousenors, the Infidelitie of Atheists, the Pestilent Practises of Pythonists, the Curiositie of Figurecasters, the Vanitie of Dreamers, the Beggerlie Art of Alcumystrie, the Abhomination of Idolatrie, the Horrible Art of Poisoning, the Vertue and Power of Naturall Magike, and all the Conueiances of Legierdemaine and Iuggling are Deciphered: and Many other Things Opened, Which Have Long Lien Hidden, Howbeit Verie Necessarie to be Knowne. Heerevnto is Added a Treatise Vpon the Nature and Substance of Spirits and Diuels, \&c: All Latelie Written by Reginald Scot Esquire, 2nd edn. EEBO, STC/21864.

Sterry, Peter. 1645. The Spirits Conviction of Sinne, Opened in a Sermon Before the Honorable House of Commons, Assembled in Parliament Upon the Solemne day of their Monethly Fast, Novemb. 26, 1645. / By Peter Sterry, Sometimes Fellow of Emanuel Colledge in Cambridge. And Now preacher of the Gospel in London. Published by Order of the House of Commons, 2nd edn. EEBO, Wing/S5485.

Swan, John. 1603. A Treve and Breife Report, of Mary Glouers Vexation and of Her Deliuerance by the Meanes of Fastinge and Prayer. Performed by Those Whose Names are Sett Downe, in the Next page. By Iohn Swan, Student in Divinitie, 2nd edn. EEBO, STC/23517.

Trapp, John. 1646. A Commentary or Exposition Upon the Four Evangelists, and the Acts of the Apostles: Wherein the Text is Explained, Some Controversies are Discussed, Divers Common Places are Handled, and Many Remarkable Matters Hinted, That Had by Former Interpreters Been Pretermitted. Besides, Divers Other Texts of Scripture Which Occasionally Occur are Fully Opened, and the Whole so Intermixed with Pertinent Histories, as Will Yeeld Both Pleasure and Profit to the Judicious Reader, 2nd edn. EEBO, Wing/T2042, Wing/T2037, Thomason/ E.376[1], Thomason/ E.376[2].

Trapp, John. 1637. Gods Love-Tokens, and the Afflicted Mans Lessons Brought to Light, and Layd Before Him in Two Fruitfull and Seasonable Discourses Upon Revel. 3. 19. Comforting Under, and Directing Unto a Right Use of Our Personall, and Publike Crosses and Calamities. By John Trapp, M.A. and Preacher of Gods Word at Luddington in Warwick-shire, 2nd edn. EEBO, STC/24175. 
Trapp, John. 1641. Theologia theologiae, the True Treasure, or, A Treasury of Holy Truths, Touching Gods Word, and God the Word digg'd up, and Drawn Out of That Incomparable Mine of Unsearchable Mystery, Heb. I. 1, 2, 3: Wherein the Divinity of the Holy Scriptures is Asserted, and Applied. EEBO, Wing/T2047.

Tymme, Thomas. 1592. A Plaine Discouerie of Ten English Lepers, Verie Noisome and Hurtfull to the Church and Common Wealth Setting Before our Eies the Iniquitie of these Latter dayes, and Inducing Us to a Due Consideration of Our Selues. Published by Thomas Timme Minister, 2nd edn. EEBO, STC/24418.

Ward, Nathaniel. 1994 [1647]. The Simple Cobbler of Aggavvam in America Willing to Help Mend His Native Country, Lamentably Tattered, Both in the Upper-Leather and Sole, with All the Honest Stitches He Can Take. And As Willing Never to be Paid for His Work, by Old English Wonted Pay. It is His Trade to Patch All the Year Long, Gratis. Therefore I Pray Gentlemen Keep your Purses, 2nd edn. EEBO, Wing/W786A.

\section{SECONDARY SOURCES}

Adams, Gwenfair Walters. 2007. Visions in late medieval England: Lay spirituality and sacred glimpses of the hidden worlds of faith. Leiden: Brill.

Bailey, Michael. 2003. Battling demons: Witchcraft, heresy, and reform in the Late Middle Ages. Philadelphia: Pennsylvania University Press.

Bailey, Michael. 2013. Fearful spirits, reasoned follies: The boundaries of superstition in late medieval Europe. Ithaca, NY: Cornell University Press.

Barry, Jonathan. 1996. Introduction: Keith Thomas and the problem of witchcraft. In Jonathan Barry, Marianne Hester \& Gareth Roberts (eds.), Witchcraft in Early Modern Europe: Studies in culture and belief, 1-48. Cambridge: Cambridge University Press.

Biale, David. 2007. Blood and belief: The circulation of a symbol between Jews and Christians. Berkeley \& Los Angeles: University of California Press.

Brantley, Jessica. 2007. Reading in the wilderness: Private devotion and public performance in late medieval England. Chicago: Chicago University Press.

Broedel, Hans Peter. 2003. The "Malleus Malleficarum" and the construction of witchcraft: Theology and popular belief. Manchester: Manchester University Press.

Bruaene, Anne-Laure van. 2016. Embodied piety: Sacrament houses and iconoclasm in the sixteenthcentury Low Countries. BMGN - Low Countries Historical Review 131(1). 36-58. DOI: 10.18352/bmgn-lchr.10178

Bryan, Jennifer. 2008. Looking inward: Devotional reading and the private self in late medieval England. Philadelphia: University of Pennsylvania Press.

Caciola, Nancy. 2003. Discerning spirits: Divine and demonic possession in the Middle Ages. Ithaca, NY: Cornell University Press.

Classen, Albrecht (ed.). 2004. Violence in medieval courtly literature: A casebook. New York: Routledge.

Classen, Albrecht (ed.). 2015. Mental health, spirituality, and religion. Berlin \& New York: Walter de Gruyter.

Cleave Alexander, Michael van. 1990. The growth of English education, 1348-1648. Philadelphia: Pennsylvania University Press.

Collinson, Patrick. 2004. The Reformation: A history. London: Orion Publishing Group. 
Como, David. 2000. Puritans, predestination and the construction of orthodoxy in early seventeenthcentury England. In Peter Lake \& Michael Questier (eds.), Conformity and orthodoxy in the English church, c.1560-1660, 64-87. Woodbridge: The Boydell Press.

Coudert, Alison. 2011. Religion, magic, and science in Early Modern Europe and America. Santa Barbara: Praeger.

Crawford, Julie. 2005. Marvelous Protestantism: Monstrous births in post-Reformation England. Baltimore: John Hopkins University Press.

Cummings, Brian \& Joseph Simmons (eds.). 2011. Cultural reformations. Oxford: Oxford University Press.

Delbanco, Andrew. 1989. The Puritan ordeal. Cambridge: Harvard University Press.

Demaitre Luke. 2007. Leprosy in premodern medicine: A malady of the whole body. Baltimore, MD: John Hopkins University Press.

Dijkhuizen, Jan Frans van. 2007. Devil theatre: Demonic possession and exorcism in Renaissance drama 1558-1642. Woodbridge: D. S. Brewer.

Duffy, Eamon. 1992. Stripping of the altars. New Haven: Yale University Press.

Duffy, Eamon. 1996. Continuity and divergence in Tudor religion. In R. N. Swanson (ed.), Unity and diversity in the church, 171-205. Oxford: Blackwell. DOI: $10.1017 / \mathrm{S} 0424208400015400$

Dykema, Peter A. 2000. Handbooks for pastors: Late medieval manuals for parish priests and Conrad Porta's Pastorale Lutheri (1582). In Robert J. Bast \& Andrew C. Gow (eds.), Continuity and change: The harvest of late medieval and Reformation history, 143152. Leiden: Brill.

Edson, Gary. 2012. Mysticism and alchemy through the ages: The quest for transformation. Jefferson, NC: McFarland \& Co.

Eire, Carlos. 2016. Reformations: The early modern world, 1450-1650. New Haven: Yale University Press.

Firey, Abigail (ed.). 2008. A new history of penance. Brill: Leiden.

Freeman, Thomas. 2000. Demons, deviance, and defiance: John Darrell and the politics of exorcism in late Elizabethan England. In Peter Lake \& Michael Questier (eds.), Conformity and orthodoxy in the English church, c. 1560-1660, 34-63. Woodbridge: Boydell \& Brewer.

Gilman, Ernest B. 2009. Plague writing in Early Modern England. Chicago: University of Chicago Press.

Godbeer, Richard. 1992. The Devil's dominion: Magic and religion in early New England. Cambridge: Cambridge University Press.

Grant, Edward. 2001. God and reason in the Middle Ages. Cambridge: Cambridge University Press. Grigsby, Byron Lee. 2004. Pestilence in medieval and Early Modern English literature. New York: Routledge.

Haigh, Christopher (ed.). 1987. The English Reformation revisited. Cambridge: Cambridge University Press.

Haigh, Christopher. 1993. English reformations: Religion, politics, and society under the Tudors. Oxford: Oxford University Press.

Hall, David. 1990. Worlds of wonder, days of judgement: Popular religious belief in early New England. Cambridge: Harvard University Press.

Hamilton, Sarah \& Andrew Spicer. 2005. Defining the holy: Delineation of sacred space. In Sarah Hamilton \& Andrew Spicer (eds.), Defining the holy: Sacred space in medieval and Early Modern Europe, 1-26. Aldershot: Ashgate. 
Hamm, Berndt. 2004. The Reformation of faith in the context of late medieval theology and piety. Leiden: Brill.

Harper-Bill, Christopher. 2014. The pre-Reformation church in England 1400-1530. London: Routledge.

Harris, Jonathan Gill. 1998. Foreign bodies and the body politic: Discourses of social pathology in Early Modern England. Cambridge: Cambridge University Press.

Hayes, Mary. 2011. Divine ventriloquism in medieval English literature. New York: Palgrave Macmillan.

Hill, Christopher. 1961. The century of revolution, 1603-1714. London: Routledge.

Hudson, Anne. 1985. Lollards and their books. Oxford: Hambledon Press.

Hudson, Anne. 1988. The premature reformation. Wycliffite texts and lollard history. Oxford: Clarendon Press.

Johnstone, Nathan. 2006. Exorcism. In Francis Bremer \& Tom Webster (eds.), Puritans and Puritanism in Europe and America. A comprehensive encyclopedia. Vol. 1, 389-390. Santa Barbara: ABC CLIO.

Kapitaniak, Pierre. 2016. Reginald Scott and the circles of power: Witchcraft, anti-Catholicism and faction politics. In Marcus Harmes \& Vitoria Bladen (eds.), Supernatural and secular power in Early Modern England, 41-66. London: Routledge.

Katajala-Peltomaa, Sari. 2014. Demonic possession as physical and mental disturbance in later medieval canonization processes. In Sari Katajala-Peltomaa \& Susanna Niiranen (eds.), Mental (dis)orders in later medieval Europe, 108-127. Leiden: Brill. DOI: 10.1163/9789004269743_007

Keen, Elizabeth. 2007. Journey of a book: Bartholomew the Englishman and the properties of things. Canberra: ANU Press.

Kibler, William \& Barton Palmer (eds.). 2014. Medieval Arthurian epic and romance: Eight new translations. Jefferson, NC: McFarland \& Co.

Kieckhefer, Richard. 1976. European witch trials. Berkeley \& Los Angeles: University of California Press.

Kieckhefer, Richard. 1989. Magic in the Middle Ages. Cambridge: Cambridge University Press.

Kieckhefer, Richard. 1997. Forbidden rites. Philadelphia: Pennsylvania State University Press.

Kors, Alan Charles \& Erin Peters. 2001. Witchcraft in Europe, 400-1700: A documentary history. Philadelphia: University of Pennsylvania Press.

Lake, Peter. 1982. Moderate Puritans and the Elizabethan church. Cambridge: Cambridge University Press.

Lawton, David. 2002. Englishing the Bible, 1066-1549. In David Wallace (ed.), The Cambridge history of medieval English literature, 454-460. Cambridge: Cambridge University Press. DOI: 10.1017/CHOL9780521444200.021

Lenski, Noel (ed.). 2006. The Cambridge companion to the age of Constantine. New York: Cambridge University Press.

Levack, Brian. 2006. The witch-hunt in Early Modern Europe. New York: Routledge.

Levack, Brian. 2013. The devil within: Possession and exorcism in the Christian West. New Haven: Yale University Press.

Lieu, Samuel N. C. \& Dominic Montserrat. 1996. From Constantine to Julian: Pagan and Byzantine views; a source history. New York: Routledge.

Lutton, Robert. 2006. Lollardy and orthodox religion in pre-Reformation England. Woodbridge: Boydell \& Brewer. 
Malo, Robyn. 2013. Relics and writing in late medieval England. Toronto: University of Toronto Press.

Marshall, Peter. 1997. Fear, purgatory, and polemic in Reformation England. In William G. Naphy \& Penny Roberts (eds.), Fear in early modern society, 150-166. Manchester: Manchester University Press.

Marshall, Peter. 2002. Belief and the dead in Reformation England. Oxford: Oxford University Press.

Marshall, Peter. 2007. Mother Leakey and the bishop: A ghost story. Oxford: Oxford University Press.

Marshall, Peter. 2012. Reformation England 1480-1642. New York: Bloomsbury.

Martin, Jessica \& Alec Ryrie (eds.). 2016. Private and domestic devotion in Early Modern Britain. London: Routledge.

Maxwell-Stuart, P. G. 2002. Rational superstition: The writings of Protestant demonologists. In Helen Parish \& William G. Naphy (eds.), Religion and superstition in Early Modern Europe, 170-187. Manchester: Manchester University Press.

Merrifield, Ralph. 1987. The archeology of ritual magic. Amsterdam: B.T. Batsdorf.

Milner, Mathew. 2011. The senses and the English Reformation. London: Routledge.

Milway, Michael. 2000. Forgotten best-sellers from the dawn of the Reformation. In Robert J. Bast \& Andrew C. Gow (eds.), Continuity and change: The harvest of late medieval and Reformation history, 113-142. Leiden: Brill.

Morgan, John. 1988. Godly learning: Puritan approaches to reason. Cambridge: Cambridge University Press.

Murdoch, Brian. 2000. Adam's grace: Fall and redemption in medieval literature. Woodbridge: D. S. Brewer.

Ozment, Stephen. 1980. The age of reform 1250-1550. New Haven: Yale University Press.

Trinkhaus, Charles \& Heiko Oberman (eds.). 1974. The pursuit of holiness in late medieval and Renaissance religion. Leiden: Brill.

Patterson, Mary Hampson. 2007. Domesticating the Reformation: Protestant best-sellers, private devotion, and the revolution of English piety. Madison: Fairleigh Dickinson University Press.

Rider, Catherine. 2014. Demons and mental disorder in late medieval medicine. In Sari KatajalaPeltomaa \& Susanna Niiranen (eds.), Mental (dis)order in later medieval Europe, 4769. Leiden: Brill. DOI: 10.1163/9789004269743_004

Risse, Guenter B. 1999. Mending bodies, saving souls: A history of hospitals. Oxford: Oxford University Press.

Rubin, Miri. 1991. Corpus Christi: The Eucharist in late medieval culture. Cambridge: Cambridge University Press.

Ryrie, Alec. 2013. Being Protestant in Reformation Britain. Oxford: Oxford University Press.

Sands, Kathleen R. 2000. The doctrine of transubstantiation and the English Protestant dispossession of demons. History 85(279). 446-462. DOI: 10.1111/1468-229X.00156

Saunders, Corinne. 2008. Bodily narratives. In Neil Cartridge (ed.), Boundaries in medieval romance, 175-190. Woodbridge: D. S. Brewer.

Saunders, Corinne. 2010. Magic and the supernatural in medieval English romance. Woodbridge: D. S. Brewer.

Stannard, David. 1977. The Puritan way of death: A study in religion, culture, and social change. Oxford: Oxford University Press. 
Swanson, R. N. 2007. Indulgences in late medieval England: Passports to paradise? Cambridge: Cambridge University Press.

Thomas, Keith. 1973. Religion and the decline of magic. London: Penguin.

Tilton, Hereward. 2003. The quest for the phoenix: Spiritual alchemy and rosicrucianism in the work of count Michael Maier (1569-1622). Berlin: De Gruyter.

Wallis, Faith. 2010. Medieval medicine: A reader. Toronto: University of Toronto Press.

Walsham, Alexandra. 2008. The Reformation and the 'disenchantment of the world' reassessed. The Historical Journal 51(2), 497-528. DOI: 10.1017/S0018246X08006808

Watkins, C. S. 2007. History and the supernatural in medieval England. Cambridge: Cambridge University Press.

Wenegrat, Brant. 2001. Theatre of disorders: Patients, doctors, and the construction of illness. Oxford: Oxford University Press.

Williams, Gerhild Scholz. 2013. Demonologies. In Brian P. Levack (ed.), The Oxford handbook of witchcraft in Early Modern Europe and Colonial America, 69-83. Oxford: Oxford University Press. DOI: 10.1093/oxfordhb/9780199578160.013.0005

Young, Francis. 2016. A history of exorcism in Catholic Christianity. New York: Springer.

Zaret, David. 1985. The heavenly contract: Ideology and organization in pre-revolutionary Puritanism. Chicago: Chicago University Press. 